Pacific Northwest National Laboratory

Operated by Battelle for the U.S. Department of Energy

\title{
Evaluation of a Vitrification Processing Step for Rocky Flats Incinerator Ash
}

\author{
J. K Luey \\ R. D. Scheele \\ H. Li \\ H. L. Wigent
}

March 1999

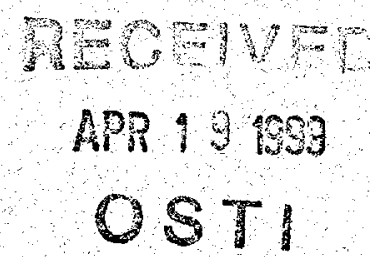

Prepared for the U.S. Department of Energy under Contract DE-AC06-76RLO 1830 


\title{
DISCLAIMER
}

This report was prepared as an account of work sponsored by an agency of the United States Government. Neither the United States Government nor any agency thereof, nor Battelle Memorial Institute, nor any of their employees, makes any warranty, express or implied, or assumes any legal liability or responsibility for the accuracy, completeness, or usefulness of any information, apparatus, product, or process disclosed, or represents that its use would not infringe privately owned rights. Reference herein to any specific commercial product, process, or service by trade name, trademark, manufacturer, or otherwise does not necessarily constitute or imply its endorsement, recommendation, or favoring by the United States Government or any agency thereof, or Battelle Memorial Institute. The views and opinions of authors expressed herein do not necessarily state or reflect those of the United States Government or any agency thereof.

\author{
PACIFIC NORTHWEST NATIONAL LABORATORY \\ operated by \\ BATTELLE \\ for the \\ UNITED STATES DEPARTMENT OF ENERGY \\ under Contract DE-AC06-76RLO 1830
}

Printed in the United States of America

Available to DOE and DOE contractors from the

Office of Scientific and Technical Information, P.O. Box 62, Oak Ridge, TN 37831; prices available from (615) 576-8401.

Available to the public from the National Technical Information Service, U.S. Department of Commerce, 5285 Port Royal Rd., Springfield, VA 22161 


\section{DISCLAIMER}

Portions of this document may be illegible in electronic image products. Images are produced from the best available original document. 
PNNL-12102

UC-2000

\title{
Evaluation of a Vitrification Processing
} Step for Rocky Flats Incinerator Ash

\author{
J. Luey \\ R.D. Scheele \\ H. Li \\ H. L. Wigent
}

March 1999

Prepared for

the U.S. Department of Energy,

under Contract DE-AC06-76RLO 1830

Pacific Northwest National Laboratory

Richland, Washington 99352 


\section{Executive Summary}

Pacific Northwest National Laboratory (PNNL) staff have completed a series of tests to evaluate a recommended vitrification processing step for plutonium-bearing incinerator ash located at the Rocky Flats Environmental Technology Site (RFETS). Testing was performed at a prototypical scale using nonradioactive surrogates and at small scale using Pu-bearing incinerator ash representative of RFETS materials. The following observations and conclusions were made from these two sets of tests.

- $\quad$ For both the small-scale and full-scale tests, process upsets were not observed when a fully calcined ash was vitrified. For the full-scale tests, complete calcination was determined from offgas data collected during calcination. For the small-scale tests, the degree of calcination was determined from thermogravimetric analysis (TGA) of the calcined ash.

- For full-scale tests, four hours were required to heat the entire contents of a container to $700^{\circ} \mathrm{C}$. Another four hours were required for the center of the container to cool to $200^{\circ} \mathrm{C}$. Forced cooling was not used.

- For full-scale tests, using a finer glass frit ( $<200$ mesh size) decreased the time required to heat the container contents relative to a coarser glass frit $(\approx 80$ mesh size). The decrease in time was typically $25 \%$.

- All full-scale tests subjected to the recoverability test easily passed the criterion of $15 \mathrm{~g} \mathrm{Ce} / \mathrm{kg}$ final product. Samples from tests that did not experience process upsets were about five times better than the results from a test run that experienced $40+\%$ volume expansion during processing (e.g., five times less cerium was recovered for samples from tests that did not experience process upsets).

- Small-scale tests verified that a good final product could be made with the selected glass frit. Five out of the six radioactive final products passed the recoverability test criterion of $15 \mathrm{~g} \mathrm{Pu} / \mathrm{kg}$ final product. The one sample that did not pass had experienced significant volume expansion during vitrification.

- $\quad$ Results from small-scale tests containing both plutonium and cerium indicate that cerium is more easily leached during the recoverability test. The difference observed was a factor of 2 to 4 . For the recoverability test, these data suggest that cerium is a conservative surrogate for plutonium. 


\section{Acknowledgments}

The authors would like to acknowledge the help received from several individuals in performing this study, preparing this document, and providing general guidance. We are grateful to Bob Elovich for his work with the plutonium-bearing ashes. We thank John Vienna for his technical review of the report. Technical editing of this report was provided by Sheila Bennett and is greatly appreciated. We wish to acknowledge all the support and guidance of Gerry Veazey and Steve McKee of LANL and Tim Burns of KH-LANL as well as Mike Finney, Laurie PetersenWright, Al Phillips, and Mike Thien at RFETS for their assistance in understanding the technology needs of the end users at RFETS. 


\section{Contents}

Executive Summary $\quad \ldots \ldots \ldots \ldots \ldots \ldots \ldots \ldots \ldots \ldots \ldots \ldots \ldots \ldots \ldots \ldots \ldots$

Acknowledgments . . . . . . . . . . . . . . . . . . .

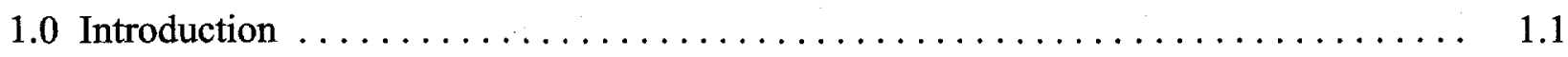

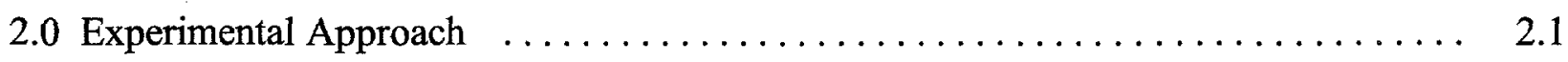

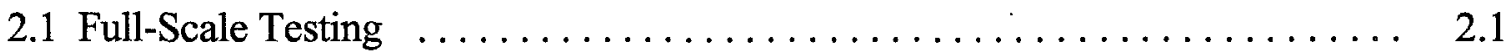

2.2 Small-Scale Testing with Plutonium-Bearing Ashes $\ldots \ldots \ldots \ldots \ldots \ldots \ldots$

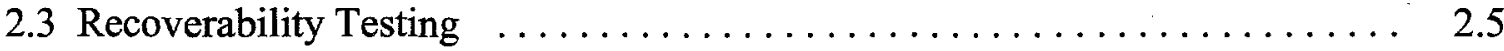

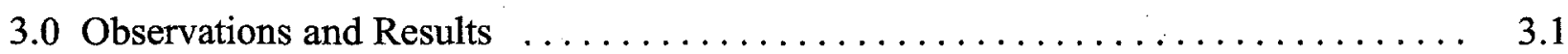

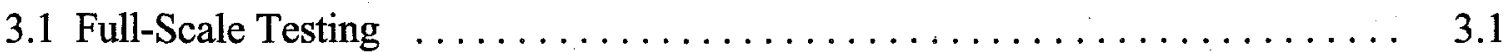

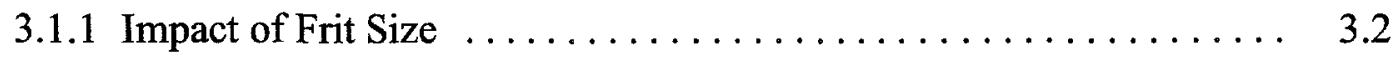

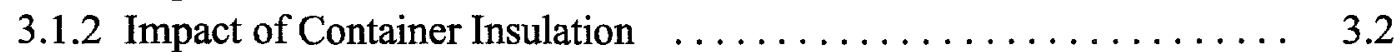

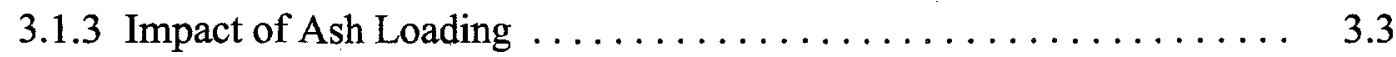

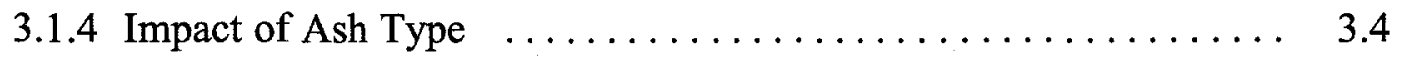

3.1.5 Impact of Carbonaceous Material $\ldots \ldots \ldots \ldots \ldots \ldots \ldots \ldots \ldots$

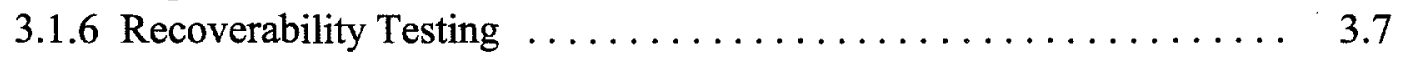

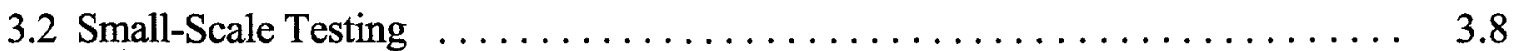

3.2.1 Preparation and Performance of RF Ash-1 $\# 1 \ldots \ldots \ldots \ldots \ldots \ldots . . .6$

3.2.2 Preparation and Performance of RF Ash-1 $\# 2 \ldots \ldots \ldots \ldots \ldots \ldots .12$

3.2.3 Preparation and Performance of BASH1H \#1 . . . . . . . . 3.13

3.2.4 Preparation and Performance of BASH1H \#2 and \#3 . . . . . . 3.15

3.2.5 Preparation and Performance of TDC193A \#1 .......... 3.17

4.0 References $\ldots \ldots \ldots \ldots \ldots \ldots \ldots \ldots \ldots \ldots \ldots \ldots \ldots \ldots \ldots \ldots \ldots \ldots \ldots \ldots$

Appendix - Temperature Profiles for Full-Scale, Nonradioactive Tests $\ldots \ldots \ldots \ldots$ A.1 


\section{Figures}

1.1 Recommended Flowsheet for Treatment of RFETS Incinerator Ash $\ldots \ldots \ldots$

2.1 Bench Top Rotary Calciner Without Stainless Steel Inner Tube $\ldots \ldots \ldots \ldots \ldots$

2.2 CM Muffle Furnace with Loading Platform Shown $\ldots \ldots \ldots \ldots \ldots \ldots \ldots \ldots$

3.1 Comparison of Selected Temperature Profiles for Coarse Versus Fine Frit Tests . . . 3.2

3.2 Comparison of Temperature Profiles with and Without Insulating Outer Container . $\quad 3.3$

3.3 Comparison of Temperature Profiles for Different Ash Loadings $\ldots \ldots \ldots \ldots . . . . .4$

3.4 Comparison of Temperature Profiles for Different Surrogate Ashes $\ldots \ldots \ldots . . . \quad 3$

3.5 Temperature Profiles for Test \#7 - Uncalcined Mix A Ash $\ldots \ldots \ldots \ldots .6$

3.6 Temperature Profile for Test \#8 - Uncalcined U of M Ash $\ldots \ldots \ldots \ldots \ldots . \ldots$

3.7 Thermal Behavior of $U$ of $M$ Ash as Measured by TGA $\ldots \ldots \ldots \ldots \ldots$

3.8 Thermal Behavior of RF Ash-1 as Measured by TGA $\ldots \ldots \ldots \ldots \ldots \ldots \ldots$

3.9 RF Ash-1 \#1 Final Product - Volume Expansion of $25 \% \ldots \ldots \ldots \ldots \ldots \ldots \ldots$

3.10 RF Ash-1 \#2 - Final Product after Foaming and Subsidence $\ldots \ldots \ldots \ldots . \ldots \ldots$

3.11 Thermal Behavior of RF BASH1H as Measured by TGA $\ldots \ldots \ldots \ldots \ldots \ldots$

3.12 Thermal Behavior of Calcined BASH1H Measured by TGA and DTA at $5^{\circ} \mathrm{C} / \mathrm{min} \quad \ldots \quad 3.14$

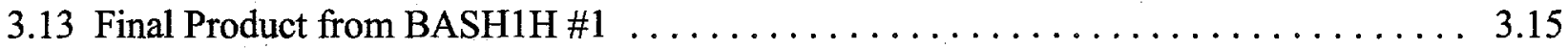

3.14 Final Product from BASH1H \#2 $\ldots \ldots \ldots \ldots \ldots \ldots \ldots \ldots \ldots \ldots \ldots \ldots$

3.15 Thermal Behavior of As-Received BASH1H as Measured by TGA and DTA . . . 3.17

3.16 Thermal Behavior of TDC193A Incinerator Ash as Measured by TGA . . . . . . 3.18 


\section{Tables}

2.1 Composition of Ash Surrogates Before Calcination $\ldots \ldots \ldots \ldots \ldots \ldots \ldots \ldots .2 .2$

2.2 Composition of the NBS-1 Alkali Borosilicate Glass Frit $\ldots \ldots \ldots \ldots \ldots \ldots .2 .3$

3.1 Summary of Test Conditions for Full-Scale Vitrification Studies $\ldots \ldots \ldots \ldots \ldots \ldots$

3.2 Summary of Small-Scale Ash Vitrification Tests $\ldots \ldots \ldots \ldots \ldots \ldots \ldots \ldots \ldots$ 


\subsection{Introduction}

In 1997, Pacific Northwest National Laboratory (PNNL) staff developed a processing option for incinerator ash at the Rocky Flats Environmental Technology Sites (RFETS). This work was performed with support from Los Alamos National Laboratory (LANL) and Safe Sites of Colorado (SSOC). A description of the remediation needs for the RFETS incinerator ash is provided in a report summarizing the recommended processing option for treatment of the ash (Luey et al. 1998).

The recommended process flowsheet involves a calcination pretreatment step to remove carbonaceous material followed by a vitrification processing step for a mixture of glass frit and calcined incinerator ash. Using the calcination pretreatment step to remove carbonaceous material reduced process upsets for the vitrification step, allowed for increased waste loading in the final product, and improved the quality of the final product. Figure 1.1 illustrates the flow sheet for the recommended processing option for treatment of RFETS incinerator ash.

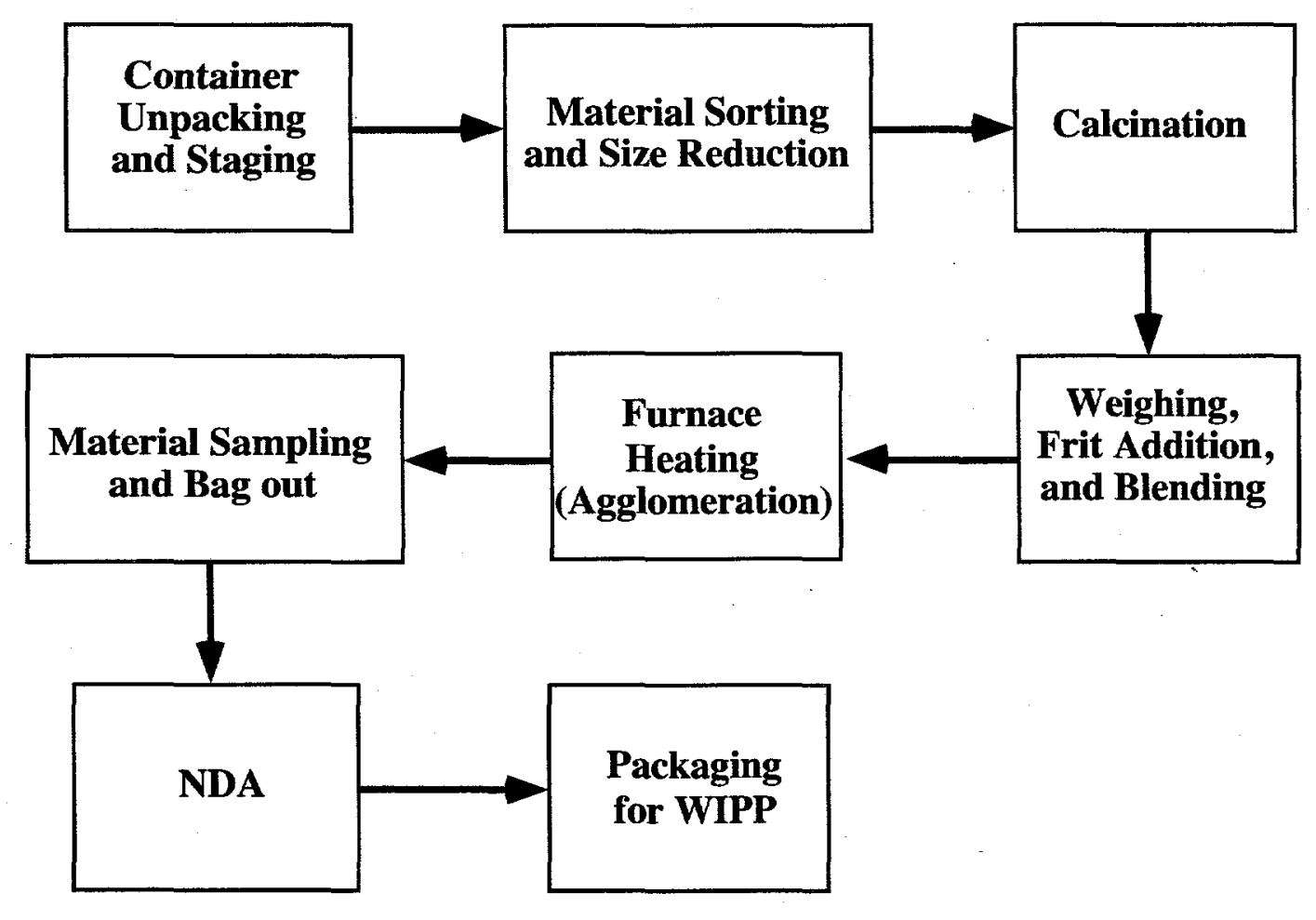

Figure 1.1. Recommended Flowsheet for Treatment of RFETS Incinerator Ash 
In 1998, work at PNNL further developed the recommended flow sheet through a series of studies to better define the vitrification operating parameters and to address secondary processing issues (such as characterizing the offgas species from the calcination process). Because a prototypical rotary calciner was not available for use, studies to evaluate the offgas from the calcination process were performed using a benchtop rotary calciner and laboratoryscale equipment (Luey et al. 1998).

This report focuses on the vitrification process step after ash has been calcined. Testing with full-scale containers was performed using ash surrogates and a muffle furnace similar to that planned for use at RFETS. Small-scale testing was performed using plutonium-bearing incinerator ash to verify performance of the waste form. Ash was not obtained from RFETS because of transportation requirements to calcine the incinerator ash prior to shipment of the material. Because part of PNNL's work was to characterize the ash prior to calcination and to investigate the effect of calcination on product quality, representative material was obtained from LANL. Ash obtained from LANL was selected based on its similarity to that currently stored at RFETS. The plutonium-bearing ashes obtained from LANL are likely from a RFETS incinerator, but the exact origin was not identified. 


\subsection{Experimental Approach}

Testing was performed to further develop the vitrification processing parameters for the treatment of RFETS incinerator ash. Two activities were performed in support of this effort: 1) full-scale testing using ash surrogates and a furnace similar to that proposed for use at RFETS, and 2) small-scale testing with plutonium-bearing incinerator ashes representative of RFETS ash. Full-scale tests were performed to evaluate the factors affecting processing time. Small-scale tests were performed to evaluate the performance of the final waste form with radioactive material. This section describes the general methods used to evaluate the vitrification process.

\subsection{Full-Scale Testing}

Ash surrogates were used for full-scale vitrification testing. Table 2.1 shows the composition of the ash surrogates prior to calcination. The composition for the $U$ of $\mathrm{M}$ Ash was determined using inductively coupled argon plasma with atomic emission spectroscopy (ICP-AES), with the carbon content determined from weight loss measurements. Two complimentary fusions were performed to prepare samples for analysis: one with potassium hydroxide in a nickel crucible and the other with sodium peroxide in a zirconium crucible. The solution from each fusion was measured with ICP-AES. The composition of the remaining ash simulants is based on the formulation prepared by the vendor. Also included in Table 2.1 is the estimated composition range of individual constituents in the RFETS incinerator ash.

Some of the ash was calcined in a benchtop rotary calciner, with the bulk of the ash calcined in batches inside of a muffle furnace (Figure 2.1 shows the rotary calciner without the inner stainless steel tube). A muffle furnace was used for calcination of the ashes because the benchtop rotary calciner was not of sufficient size to produce, in a reasonable amount of time, the kilogram quantities of calcined material needed for full-scale testing. Using a muffle furnace, two- to threekilogram batches of ash surrogate could be calcined at a time instead of the 250 -gram batch size in the rotary calciner unit. Although the rotary calciner can process material faster than the batch calciner, for a similar batch size, the need to staff the rotary calciner made a muffle furnace (which could be operated unattended overnight) the preferred calcination option for PNNL's work.

The glass frit used for full-scale testing was the alkali borosilicate glass frit NBS-1, which was developed in 1997 (Vienna et al. 1997; Vienna et al. 1998). Table 2.2 shows the composition of the NBS-1 glass frit. Two different frit sizes were used for testing: a coarse frit around 100 mesh ( $\approx 140$ microns) and a fine frit that was less than 325 mesh ( $\approx 40$ microns). Different frit sizes were used to determine whether there was a difference in heating rate for the batch (glass frit plus ash). 
Table 2.1. Composition of Ash Surrogates Before Calcination

\begin{tabular}{|c|c|c|c|c|c|c|c|c|}
\hline $\begin{array}{l}\text { Com- } \\
\text { pound }\end{array}$ & $\begin{array}{c}\mathrm{U} \text { of } \mathrm{M} \\
\text { ash }\end{array}$ & Mix A & Mix B & Mix C & Mix D & $\begin{array}{c}\text { RFETS } \\
\text { Min }\end{array}$ & $\begin{array}{c}\text { RFETS } \\
\text { Ave. }\end{array}$ & $\begin{array}{l}\text { RFETS } \\
\text { Max }\end{array}$ \\
\hline $\mathrm{SiO}_{2}$ & 29.48 & 73.17 & 14.99 & 43.29 & 14.15 & 14.17 & 48.49 & 74.10 \\
\hline $\mathrm{B}_{2} \mathrm{O}_{3}$ & 2.39 & 0.96 & 2.77 & 1.83 & 3.27 & 0.32 & 1.76 & 3.2 \\
\hline $\mathrm{Na}_{2} \mathrm{O}$ & 2.83 & & 1.22 & 0.59 & 1.44 & 0.00 & 1.20 & 2.4 \\
\hline $\mathrm{CaO}$ & 16.29 & 2.77 & 5.99 & 4.82 & 5.66 & 1.1 & 4.05 & 7.0 \\
\hline $\mathrm{MgO}$ & 2.17 & 3.86 & 5.99 & 4.83 & 5.66 & 0.83 & 4.57 & 8.3 \\
\hline $\mathrm{Fe}_{2} \mathrm{O}_{3}$ & 1.87 & 4.82 & 7.99 & 6.18 & 7.55 & 1.1 & 5.70 & 10.3 \\
\hline $\mathrm{Al}_{2} \mathrm{O}_{3}$ & 12.74 & 4.25 & 5.00 & 4.35 & 4.72 & 0.95 & 3.33 & 5.7 \\
\hline \multicolumn{9}{|l|}{$\mathrm{ZrO}_{2}$} \\
\hline $\mathrm{C}$ & 9.65 & 6.36 & 39.96 & 21.62 & 37.74 & 7.5 & 21.75 & 36.0 \\
\hline Plastic & & & & 2.42 & 4.72 & & & \\
\hline Paper & & & & 0.48 & 0.94 & & & \\
\hline $\mathrm{CeO}_{2}$ & & 1.93 & 14.99 & 8.11 & 14.15 & & & \\
\hline $\mathrm{BaO}$ & 0.39 & & & & & 0.58 & 0.89 & 1.2 \\
\hline $\mathrm{Cl}$ & 1.06 & & 0.47 & 0.23 & & 0.8 & 2.70 & 6.4 \\
\hline $\mathrm{Cr}_{2} \mathrm{O}_{3}$ & 0.05 & & & & & 0.44 & 0.66 & 0.88 \\
\hline $\mathrm{CuO}$ & & & & & & 0.63 & 0.97 & 1.3 \\
\hline $\mathrm{F}$ & & 1.88 & & 0.94 & & & & \\
\hline $\mathrm{K}_{2} \mathrm{O}$ & 1.83 & & 0.63 & 0.31 & & 0.24 & 0.72 & 1.2 \\
\hline $\mathrm{MnO}$ & 0.05 & & & & & 0.03 & 0.06 & 0.08 \\
\hline $\mathrm{NiO}$ & & & & & & 0.25 & 0.45 & 0.64 \\
\hline $\mathrm{P}_{2} \mathrm{O}_{5}$ & 11.01 & & & & & 0.23 & 0.23 & 0.23 \\
\hline $\mathrm{PbO}$ & 0.48 & & & & & 0.58 & 0.75 & 0.92 \\
\hline $\mathrm{SO}_{3}$ & 1.92 & & & & & & & \\
\hline \multicolumn{9}{|l|}{ SrO } \\
\hline $\mathrm{SnO}$ & 0.40 & & & & & 0.0 & 0.13 & 0.25 \\
\hline $\mathrm{TiO}_{2}$ & 3.75 & & & & & 1.0 & 1.35 & 1.70 \\
\hline $\mathrm{ZnO}$ & 1.64 & & & & & & & \\
\hline TOTAL & 100.00 & 100.00 & 100.00 & 100.00 & 100.00 & NA & NA & NA \\
\hline
\end{tabular}




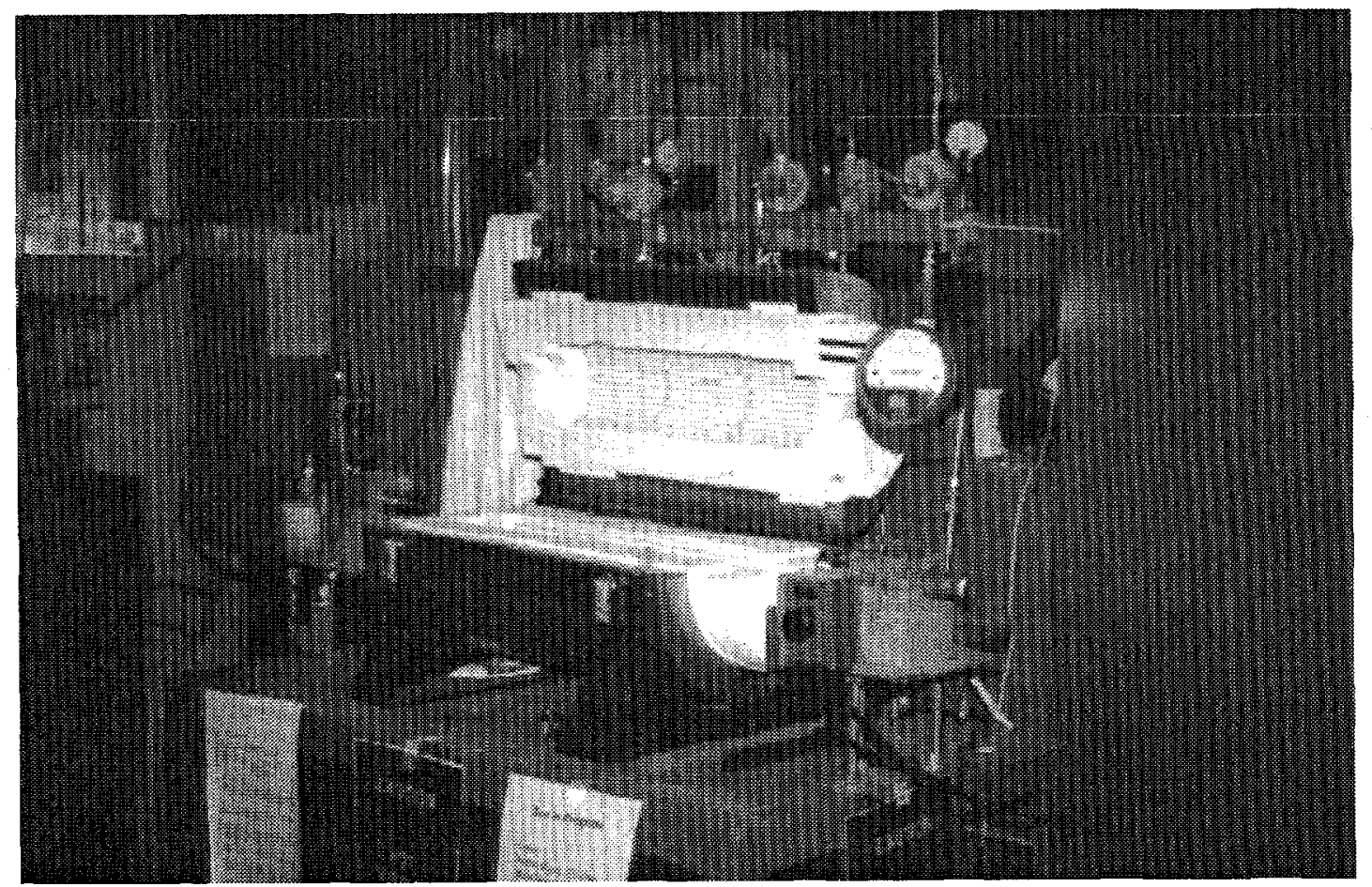

Figure 2.1. Benchtop Rotary Calciner Without Stainless Steel Inner Tube

Full-scale testing was performed in a bottom-loading muffle furnace from CM Furnaces Incorporated (Bloomfield, New Jersey). The 15-kilowatt furnace is similar in dimension and specification to furnaces planned for use at RFETS with the exception that the RFETS furnaces load through a side door and not through the bottom. A total of six molybdenum disilicide heating elements are used and are split between two opposing sides of the furnace. The furnace

Table 2.2. Composition of the NBS-1 Alkali Borosilicate Glass Frit

\begin{tabular}{|c|c|}
\hline Component & Weight Percent \\
\hline \hline $\mathrm{Al}_{2} \mathrm{O}_{3}$ & 5.0 \\
\hline $\mathrm{B}_{2} \mathrm{O}_{3}$ & 10.0 \\
\hline $\mathrm{Li}_{2} \mathrm{O}$ & 5.0 \\
\hline $\mathrm{Na}_{2} \mathrm{O}$ & 15.0 \\
\hline $\mathrm{SiO}_{2}$ & 60.0 \\
\hline $\mathrm{ZrO}_{2}$ & 5.0 \\
\hline
\end{tabular}


can be operated manually or with a programmable temperature controller connected to the power supply. The loading platform is raised and lowered by a screw mechanism that allows for variable positioning of the platform (e.g., the platform is not limited to the fully closed or fully opened position). Figure 2.2 shows the CM furnace with the platform fully lowered.

The CM furnace is equipped with an access port through the top that is oriented with the center of the platform. This port provided access for an array of type $\mathrm{K}$ thermocouples used to measure the heating profile (temperature as a function of time and position) of the material within the Vollrath container. For each test, five thermocouples were positioned along the vertical centerline at the following heights: the bottom of the can, $2.5 \mathrm{~cm}$ from the bottom, $7.5 \mathrm{~cm}$ inches from the bottom, $12.5 \mathrm{~cm}$ from the bottom, and $17.5 \mathrm{~cm}$ from the bottom. The $17.5-\mathrm{cm}$ thermocouple was usually not in the glass frit/ash mixture and tracked the furnace temperature. Data were collected and recorded at five-minute intervals.

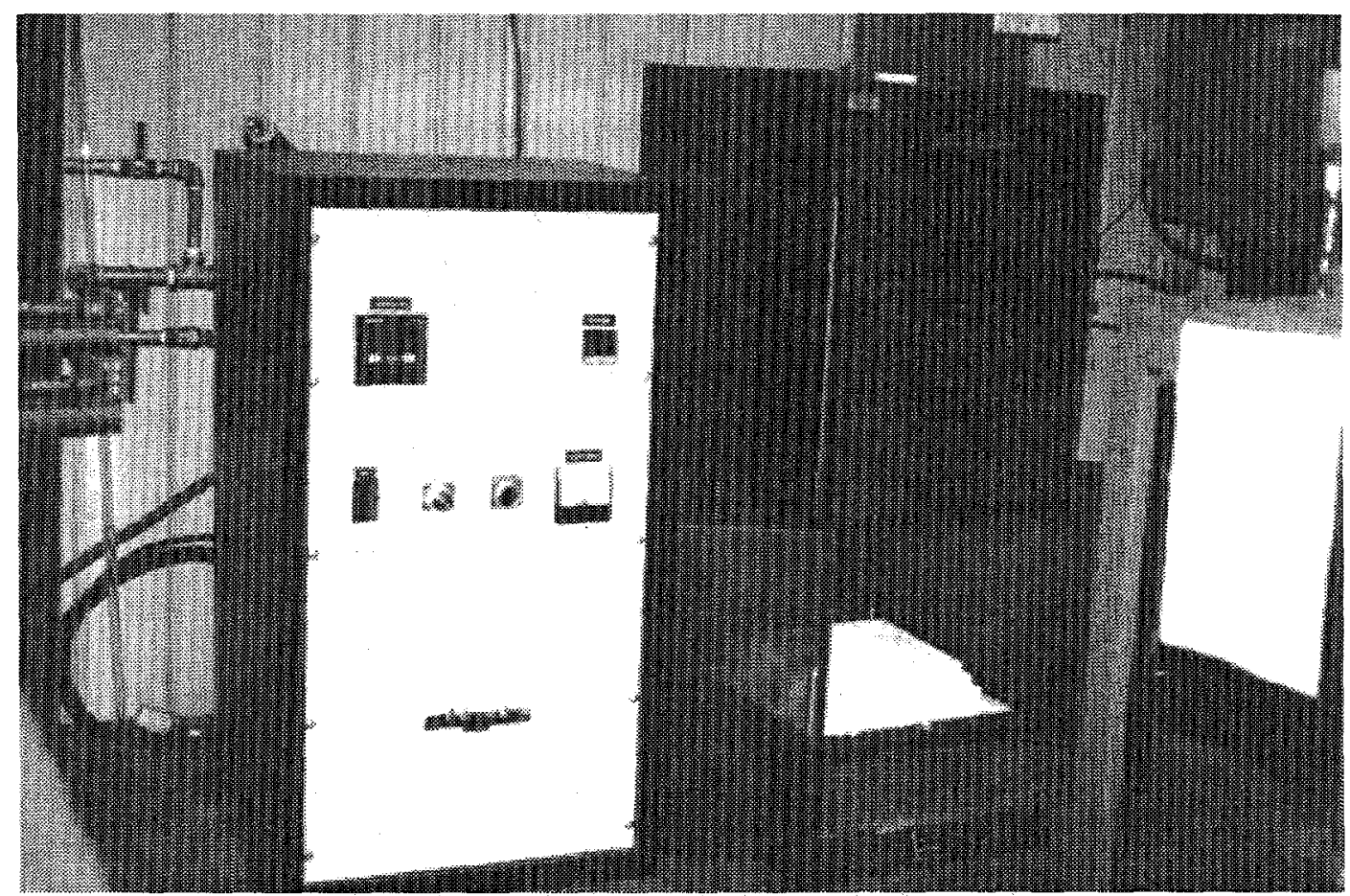

Figure 2.2. CM Muffle Furnace with Loading Platform Shown 


\subsection{Small-Scale Testing with Plutonium-Bearing Ashes}

Three different plutonium-bearing ashes were used for small-scale testing, one obtained from Hanford and two from LANL. The original source for all three ashes is believed to be RFETS, but data on the exact origins were not available. Based on limited data on the different plutonium-bearing incinerator ashes at RFETS, it is reasonable to expect that the ashes from Hanford (RF Ash-1) and LANL (BASH1H and TDC193A) will exhibit behavior similar to the material at RFETS.

All small-scale tests were performed in gloveboxes in PNNL's Radiochemical Processing Laboratory in the 300 Area of the Hanford Site. In general, the small-scale tests involved mixing as-received or pretreated ash with sufficient glass frit to yield a $2 \mathrm{wt} \% \mathrm{Pu}$ product; in some cases, a higher $\mathrm{Pu}$ content was targeted. Thermal processing for both the pretreatment and vitrification was done in a small muffle furnace. Calcination was performed at $700^{\circ} \mathrm{C}$ in either stainless steel beakers or porcelain crucibles, while the sintering used a temperature of $800^{\circ} \mathrm{C}$ and was performed in stainless steel beakers. For some of the ashes, cerium was added as cerium oxide to about the same concentration (wt\%) as the $\mathrm{Pu}$ present. The purpose of this addition was to obtain data to compare the leachability of cerium with that of plutonium. Cerium is a common surrogate for plutonium and was used in the full-scale tests. Therefore, knowing the relative leachability of cerium compared to plutonium helped to interpret the data from the full-scale tests.

To provide a solution for analysis of $\mathrm{Pu}$ content in the as-received ash, calcined ash, and sintered final product, a sodium peroxide fusion was performed. A nominal 0.2-g sample was fused with $2 \mathrm{~g}$ of sodium peroxide at 500 to $650^{\circ} \mathrm{C}$ in a zirconium crucible. The cooled fusion product was dissolved in either $0.8 \mathrm{M}$ nitric acid with added hydroxylamine hydrochloride or $0.6 \mathrm{M}$ hydrochloric acid solution with added oxalic acid.

The Pu content was determined using gamma energy analysis (GEA) and/or alpha energy analysis (AEA). Gamma analysis provides $238 \mathrm{Pu}, 239 \mathrm{Pu}, 240 \mathrm{Pu}, 241 \mathrm{Am}$, and $243 \mathrm{Am}$. Alpha analysis provides $238 \mathrm{Pu}+231 \mathrm{Am}$, and $239 \mathrm{Pu}+240 \mathrm{Pu}$. Using the $239 \mathrm{Pu}$ and $240 \mathrm{Pu}$ isotopics provided by records or by LANL's nondestructive special nuclear material assay, the Pu mass content was calculated. Note that, for many of the solutions prepared, one or more of the isotopes were below the detection limits of GEA. This prevented an accurate calculation of total Pu content. Cerium content was determined using ICP/AES.

\subsection{Recoverability Testing}

The primary measure of waste form performance was a recoverability test developed by LANL and based on previous testing to recover plutonium from residue material (Christiansen and Maraman 1969; Ziegler et al. 1971). This test was intended to provide a standardized method 
for comparing ease of plutonium recovery from wastes amenable to nitric acid dissolution or leaching. The recoverability test was used during the development of the process flowsheet for incinerator ash as a means to validate processing parameters. For example, one contributing factor for the selection of the NBS-1 glass frit over the tin zinc phosphate glass frit in 1997 was the superior performance of the NBS-1 final waste form (Luey et al. 1998).

The recoverability test procedure used to evaluate the performance of the waste form generated from PNNL testing is listed below.

1. Prepare a sample as prescribed in paragraph 7.1.3 of EPA Method 1311 (US EPA 1992). To ensure compatibility of data, it is important to maintain the particle size range within close tolerances so that surface area, which influences dissolution rate, does not vary. Therefore, fines will be removed and the procedure will be conducted on samples that pass through a $9.5-\mathrm{mm}$ sieve but retained on a $6.35-\mathrm{mm}$ sieve. Samples will be used without size reduction if they are less than $9.5 \mathrm{~mm}$ in their native state.

2. Prepare a $9 \mathrm{M}$ nitric acid solution. Add calcium fluoride to the nitric acid solution ( 0.25 moles per liter of nitric acid solution). Not all of the calcium fluoride will dissolve.

3. Proportion the ratio of solid sample to acid solution so that for every 20 grams of sample, there is $100 \mathrm{~mL}$ of acid solution.

4. Heat the acid solution to boiling, then decrease the temperature to $\approx 30^{\circ} \mathrm{C}$ below the boiling point (to avoid boilover during sample addition).

5. Add sample to the hot acid solution and heat at reflux for at least 20 minutes from the point of solid addition but not more than 30 minutes. An efficient condenser should be used so that no solution is lost.

6. Cool the mixture to a convenient handling temperature (between 20 and $60^{\circ} \mathrm{C}$ ).

7. Filter the solution through progressively finer glass Buchner funnels with fritted disks: coarse (Corning 36060-150C or equivalent), medium (Corning 36060-150M or equivalent), and fine (Corning 36060-150F or equivalent) until any of the following conditions are met:

a) the resulting solution does not exhibit cloudiness

b) the resulting solution does not scatter light

c) the fine filter has been used. 
It is permissible to go directly to the fine frit if experience has shown that the mixture is readily filterable. The intent of this step is to separate dissolved plutonium from particulate plutonium.

8. Rinse the filter(s) and any remaining solids three times with $20-\mathrm{mL}$ portions of roomtemperature $9 \mathrm{M}$ nitric acid to ensure that dissolved plutonium is removed. The first rinse aliquot should be used successively on all extraction equipment, followed by the second and third rinse aliquots.

9. Combine all filtrates and rinse aliquots and analyze for plutonium. Convert the plutonium concentration in the filtrate to the concentration leachable from $1 \mathrm{~kg}$ of final waste form. Compare the resulting plutonium recoverability number to Safeguards and Security Attractiveness Level E criteria.

For RFETS incinerator ash, the waste form was to pass a Safeguards and Security Attractiveness Level $\mathrm{E}$ criterion of $15 \mathrm{~g}$ recovered plutonium per kilogram of final waste form. For full-scale testing with nonradioactive ash surrogates, cerium was used as a surrogate for plutonium. A level of $15 \mathrm{~g}$ cerium per kilogram of final waste form was selected as equivalent to the Level $\mathrm{E}$ criterion for the full-scale product from PNNL tests. Small-scale tests with incinerator ash from LANL used the recoverability procedure as stated above. 


\subsection{Observations and Results}

Observations and results from the full-scale testing with ash surrogates and the small-scale testing with plutonium-bearing incinerator ashes are presented in this section. The discussion for fullscale testing is broken down into the different factors studied (e.g., impact of ash type, impact of frit particle size, and impact of carbon content). Results of recoverability tests performed on the full-scale waste form are discussed as one section. Results from testing with plutonium-bearing ashes are discussed together.

\subsection{Full-Scale Testing}

Unless otherwise noted, full-scale testing was performed using a stainless steel container that was $19 \mathrm{~cm}$ in diameter and $21.6 \mathrm{~cm}$ tall. For all tests, one-half hour was set as the time to bring the furnace from room temperature to $800^{\circ} \mathrm{C}$. Table 3.1 summarizes the parameters for the full-scale runs performed. Parameters of interest included frit particle size, use of a container insulating layer, ash loading, ash type, and presence of carbonaceous material. The results from the eight tests are discussed in terms of these parameters. Temperature profiles for each of the tests are included in Attachment 1.

Table 3.1. Summary of Test Conditions for Full-Scale Vitrification Studies

\begin{tabular}{|c|c|c|c|c|c|}
\hline Test \# & $\begin{array}{c}\text { Ash } \\
\text { Surrogate }\end{array}$ & $\begin{array}{l}\text { Cerium in ash } \\
\text { Initial, wt } \%\end{array}$ & $\begin{array}{l}\text { Cerium in } \\
\text { waste form } \\
\text { final, wt } \%\end{array}$ & Frit Size(a) & Ash Loading \\
\hline 1 & Mix C & 8.97 & 1.67 & Coarse & 18.47 \\
\hline 2 & Mix $C$ & 8.97 & 1.67 & Fine & 18.60 \\
\hline $3^{(b)}$ & Mix C & 8.97 & 1.67 & Coarse & 18.47 \\
\hline 4 & Mix C & 8.97 & 3.59 & Fine & 40.01 \\
\hline 5 & Mix B & 20.90 & 1.66 & Coarse & 31.83 \\
\hline 6 & Mix D & 20.90 & 1.87 & Coarse & 28.99 \\
\hline $7(b)$ & Mix A & 1.57 & 0.30 & Fine & 19.54 \\
\hline $8^{(c)}$ & $\mathrm{U}$ of $\mathrm{M}$ & 0.00 & 0.00 & Fine & 19.97 \\
\hline \multicolumn{6}{|c|}{$\begin{array}{l}\text { (a) Coarse }=100 \text { mesh, fine }=325 \text { mesh. } \\
\text { (b) Inner container processed inside a larger container. } \\
\text { (c) Tests used uncalcined ash surrogates. }\end{array}$} \\
\hline
\end{tabular}




\subsubsection{Impact of Frit Size}

Figure 3.1 compares the temperature profiles for selected thermocouples from Tests \#1 and \#2. Test \#1 used a mixture of coarse NBS-1 glass frit and calcined Ash C, while Test \#2 used a mixture of fine NBS-1 glass frit and calcined Ash C. The thermocouples selected for comparison were located $2.5 \mathrm{~cm}$ and $7.5 \mathrm{~cm}$ from the bottom of the Vollrath container. As seen in Figure 3.1, the centerline heated faster for the test with fine frit relative to that for the coarse frit. Using $700^{\circ} \mathrm{C}$ as the minimum required temperature for producing a good final product, the fine frit test reached temperature one hour faster at the $7.5-\mathrm{cm}$ location and about 30 minutes faster at the $2.5-\mathrm{cm}$ location. The reason the fine frit heats faster is probably because of better particleparticle contact, which results in better heat transfer from the outside of the container into the middle of the frit and ash surrogate mixture.

\subsubsection{Impact of Container Insulation}

For Test \#3, the Vollrath container was placed inside a larger stainless steel container $(20.3 \mathrm{~cm}$ diameter and $25 \mathrm{~cm}$ tall). The concept was to provide an overflow system in the event that foaming occurred inside of the inner Vollrath container. If the outer container could prevent

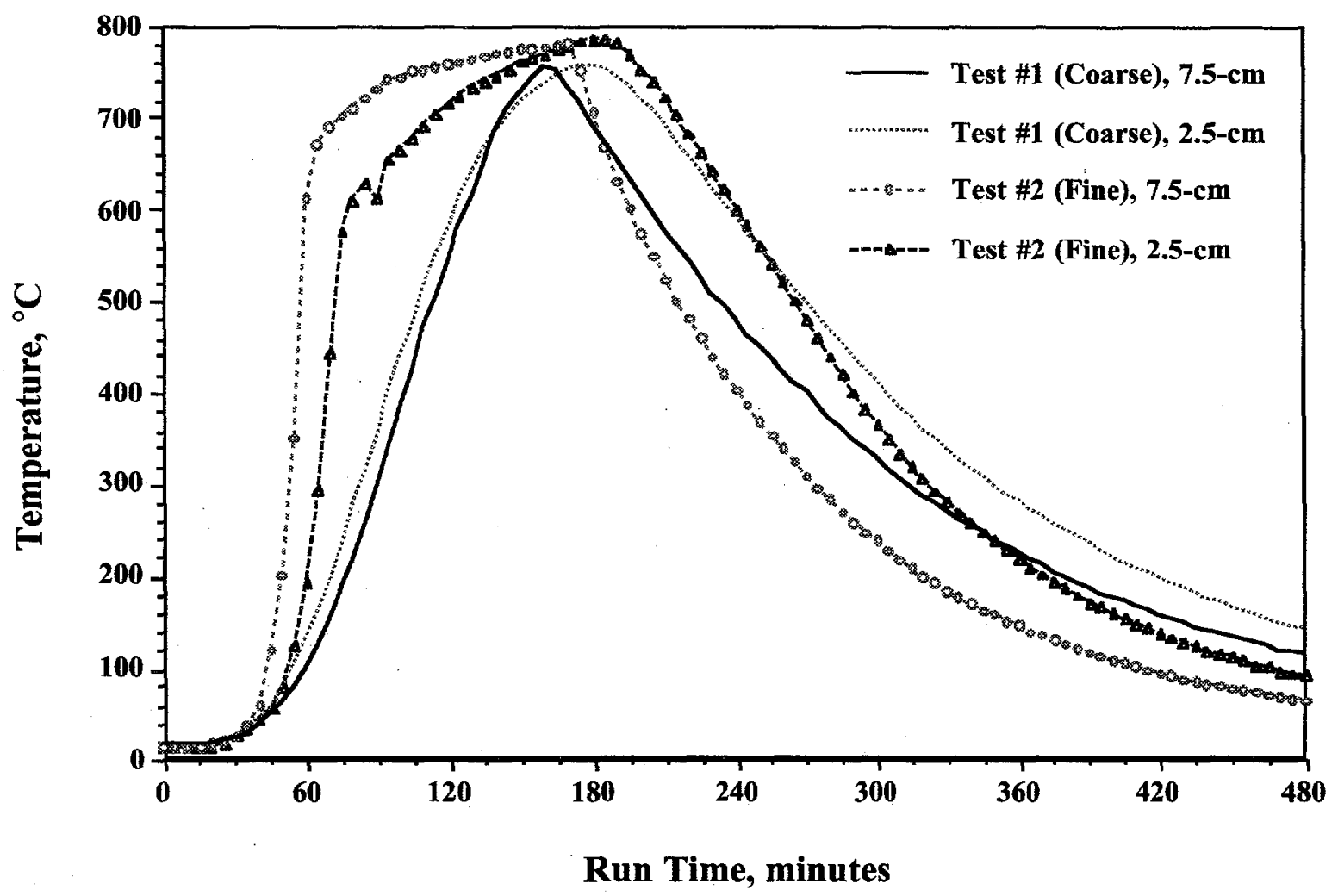

Figure 3.1. Comparison of Selected Temperature Profiles for Coarse Versus Fine Frit Tests 
material from contacting the inside of the furnace, then complete calcination, or the calcination step itself, would not be required. Calcined ash was used for Test \#3 to determine the effect that this outer container had on the heating rate. Figure 3.2 illustrates the temperature profile for selected thermocouples of Test \#1 and Test \#3. Both tests used a coarse NBS-1 frit and the same loading of calcined ash surrogate Mix C.

As seen in Figure 3.2, the presence of the outer container resulted in the centerline reaching $700^{\circ} \mathrm{C} 30$ minutes slower than the test without an outer container. The air space between the two containers in Test \#3 provides an insulating layer that reduces the heat transfer rate. This reduced rate affects both the heating and cooling of the inner container (the temperature decline is slower for Test \#3 than for Test \#1).

\subsubsection{Impact of Ash Loading}

For full-scale operation at RFETS, the amount of plutonium-bearing ash per container is limited by the plutonium content (estimated to be $87 \mathrm{~g}$ fissile gram equivalent) and final plutonium concentration. For a nominal plutonium level of $5 \mathrm{wt} \%$ in the ash, a $2 \mathrm{wt} \%$ level corresponds to

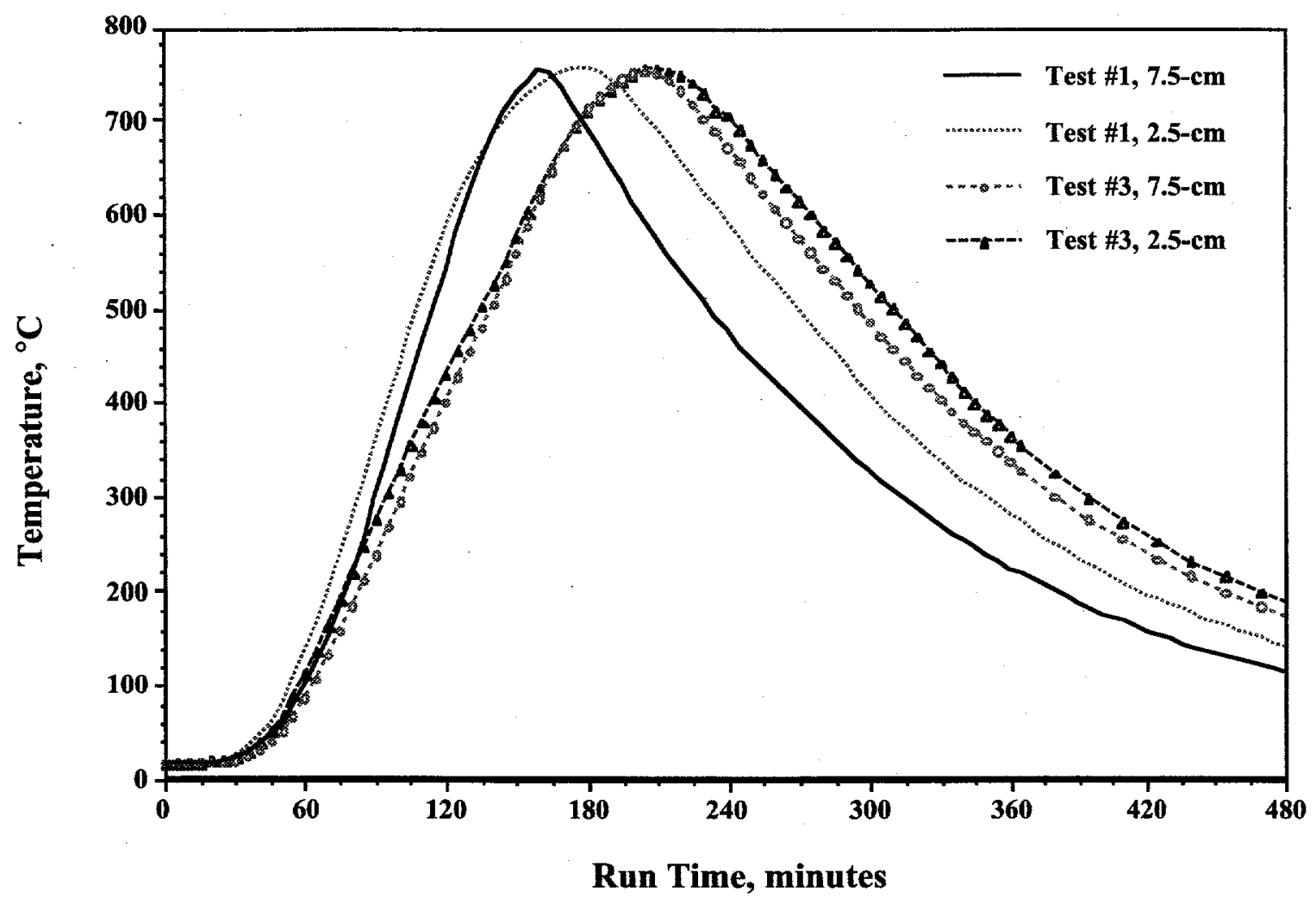

Figure 3.2. Comparison of Temperature Profiles with and Without Insulating Outer Container 
a $40 \mathrm{wt} \%$ ash loading. Work performed in 1997 showed that a $40 \mathrm{wt} \%$ ash loading required a calcined ash to consistently produce a quality final waste form (Luey et al. 1998).

Figure 3.3 illustrates the temperature profile for selected thermocouples from Tests \#2 and 4. Both tests used the calcined Mix C ash surrogate and fine NBS-1 glass frit. For the $7.5-\mathrm{cm}$ thermocouple, the higher ash loading needed about 15 minutes more than the lower ash loading to reach equivalent temperatures. This trend was also observed for the $2.5-\mathrm{cm}$ thermocouple, but the time difference was only about 5 minutes. The difference shown in the cooling portion of the curves occurs because the furnace was turned off sooner in the higher ash loading test. Since the comparable curves have similar shapes, it would be expected that the curves would almost sit on top of each other if the higher ash loading test had been heated to the same maximum temperature.

\subsubsection{Impact of Ash Type}

As seen in Table 2.2, the RFETS incinerator ash has a wide compositional range. If the main source of the composition variability is due to different levels of carbonaceous material, then the

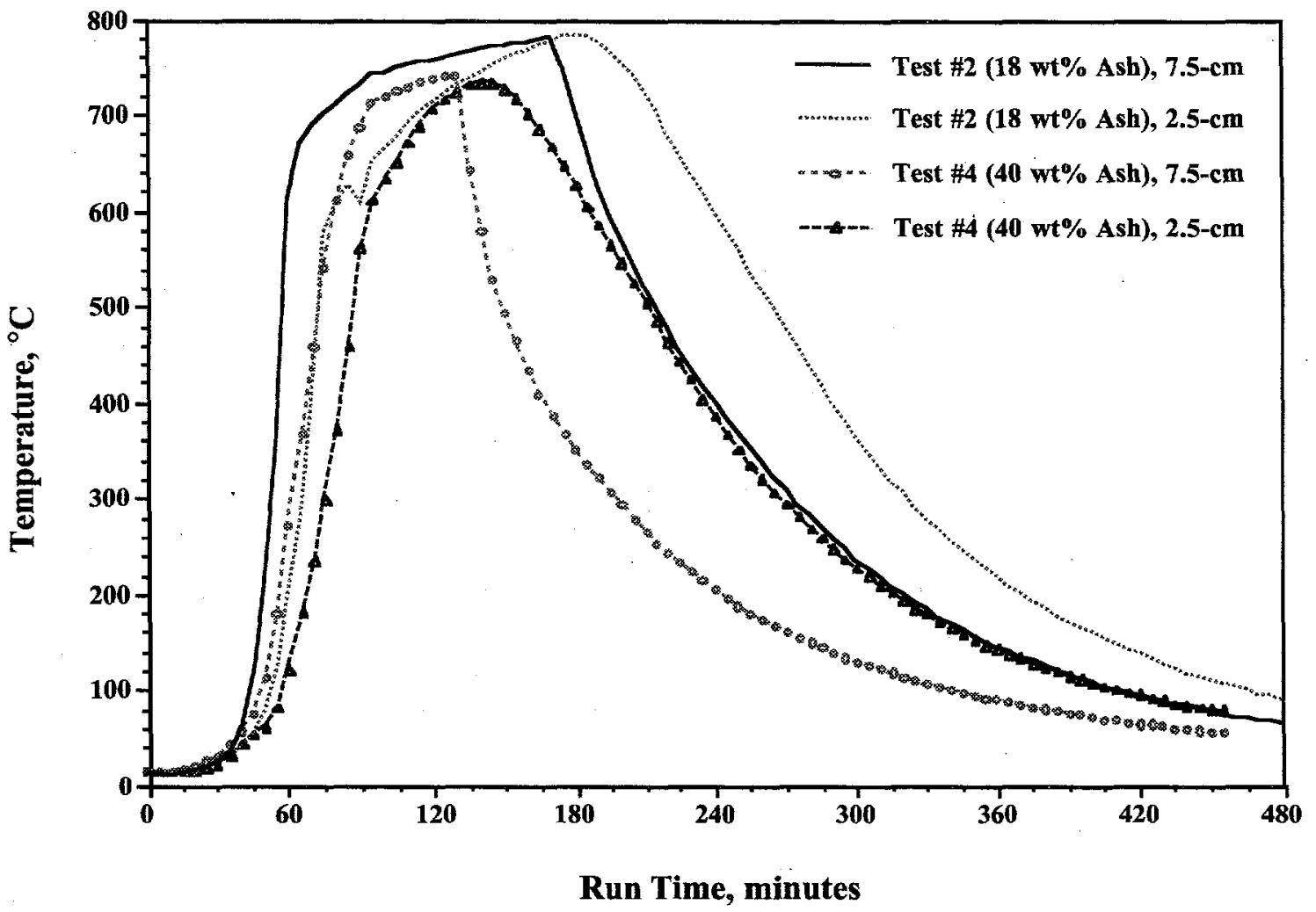

Figure 3.3. Comparison of Temperature Profiles for Different Ash Loadings 
calcination step should help to narrow the composition range and create a more uniform ash waste. If carbonaceous material is not the source of variability, then the calcination step will produce an ash with a similar composition variability but different concentration levels.

To determine the impact of composition on the vitrification process, tests were performed with calcined Mixes B, C, and D. For all three tests, a coarse NBS-1 glass frit was used. Because of the high initial cerium concentration in ash surrogates Mix B and Mix D, a $10 \mathrm{wt} \%$ ash loading would have been required to get a final cerium concentration below $2 \mathrm{wt} \%$. To achieve an ash loading more representative of the other tests, calcined and cerium-free $U$ of $M$ Ash was used to increase the ash loading for Tests \#5 and 6.

Figure 3.4 illustrates the temperature profiles of selected thermocouples for Tests \#1 and 5. Data for Test \#6 are not shown because the furnace's controller turned the furnace off early, and it had to be manually brought back to temperature. Because of this difference in heating in Test \#6, temperature comparisons cannot be made with other tests. Two complicating factors that influence the comparison are 1) different ash loading in the two tests and 2) heating to a lower temperature in Test \#5. The profiles shown in Figure 3.4 do not indicate a significant difference in heating between the two tests. Heating portions of the curves are slightly different, but the time required to reach $700^{\circ} \mathrm{C}$ is similar in the two tests. In terms of overall heating, it appears that the heating is not as uniform for Tests \#5 and 1. This is indicated by the separated temperature curves for Test \#5 and the almost identical profiles of Test \#1.

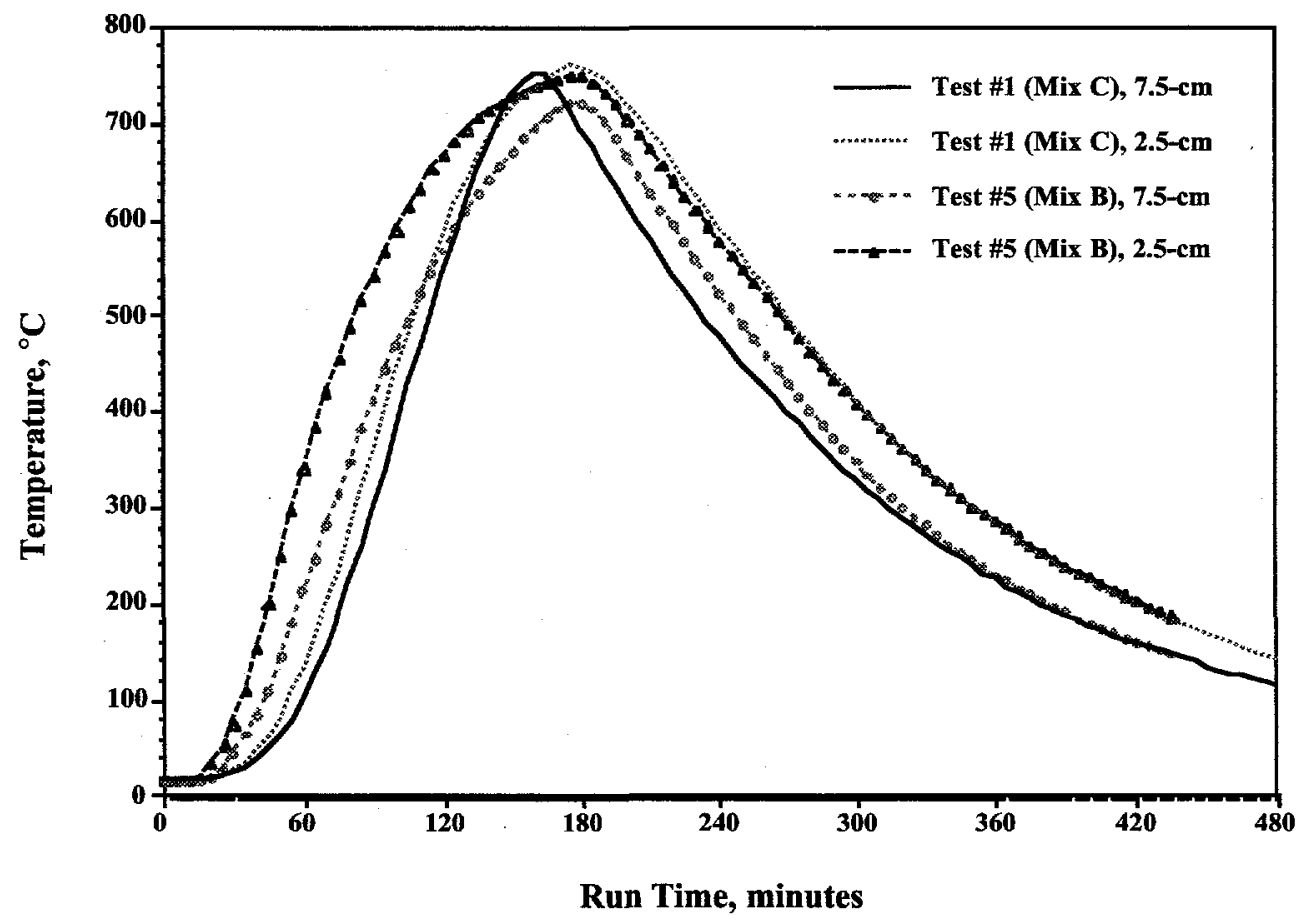

Figure 3.4. Comparison of Temperature Profiles for Different Surrogate Ashes 


\subsubsection{Impact of Carbonaceous Material}

Small-scale tests showed that, for some ash loadings, uncalcined ash caused foaming during the vitrification process step. Two tests were performed to confirm this at full scale. Test \#7 was performed with ash Surrogate Mix A and fine NBS-1 glass frit, while Test \#8 used U of M ash instead of Mix A. An ash loading of about $20 \mathrm{wt} \%$ was selected for both tests because foaming was observed at this level in tests at smaller scale. The Vollrath container was filled $50 \%$ full to allow for volume expansion.

Figure 3.5 illustrates the temperature profile for Test \#7 with the uncalcined Mix A ash surrogate. At the beginning of the test, both the $17.5-\mathrm{cm}$ and $12.5-\mathrm{cm}$ thermocouples were exposed (e.g., not embedded in the ash and frit mixture). During the first 30 minutes of heating, the profiles for these thermocouples follow the heating profile for the furnace, which was expected. However, fluctuations in the profile after 30 minutes indicate the $12.5-\mathrm{cm}$ and $17.5-\mathrm{cm}$ thermocouples were contacted by foam generated from the ash and glass frit mixture.

Post-test observations of the container from Test $\# 7$ found traces of glass on the inside of the Vollrath container above the final glass surface. Based on the glass traces, volume expansion was about $45 \%$. Using the position of the thermocouples, volume expansion was close to $100 \%$. If the container had been 80 to $90 \%$ full, the volume expansion observed for Mix A would have overflowed the container and contacted the ceiling of the furnace.

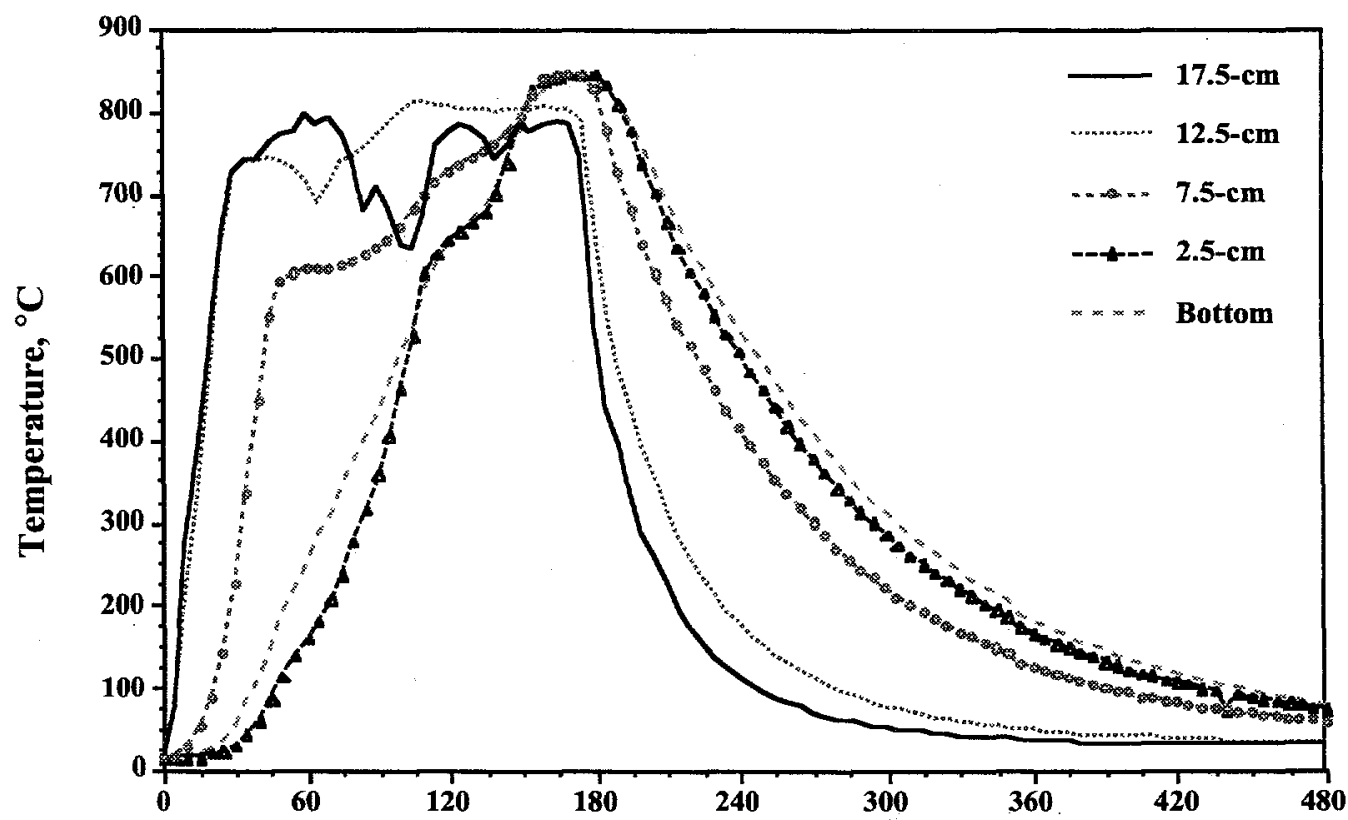

Time, minutes

Figure 3.5. Temperature Profiles for Test \#7 - Uncalcined Mix A Ash 
Figure 3.6 illustrates the temperature profile for Test \#8, which used uncalcined $U$ of $M$ ash ( $9.4 \mathrm{wt} \%$ carbon). As seen for Test \#7, the temperature profile for the $12.5-\mathrm{cm}$ and $17.5-\mathrm{cm}$ thermocouples matched that of the furnace. After the furnace was at temperature, the readings from the $12.5-\mathrm{cm}$ thermocouple indicate contact with foam from the ash and glass frit mixture. Some foam may have contacted the $17.5-\mathrm{cm}$ thermocouple. Post-test observations did not identify any glass on the sides of the container above the initial height of the mixture suggesting that the foaming was localized to the center of the container and was not that extensive. Based on the location of the $12.5-\mathrm{cm}$ thermocouple relative to the initial height of the mixture, the volume expansion was estimated to be about $25 \%$. The observed difference in degree of volume expansion is due to the different carbon material in each ash surrogate. Mix A contained graphite and was composed of raw chemicals. The $\mathrm{U}$ of $\mathrm{M}$ ash is from a medical incinerator and contains carbonaceous material of unknown type.

\subsubsection{Recoverability Testing}

Samples from Tests \#1, \#4, and \#7 were subjected to the recoverability. These tests were selected because they represent a range of observed subsidence. Test \#4 showed the greatest subsidence (43.9\%) followed by Test \#1 (35.8\%) and Test \#7 (11.6\%). In fact, Test \#7 had

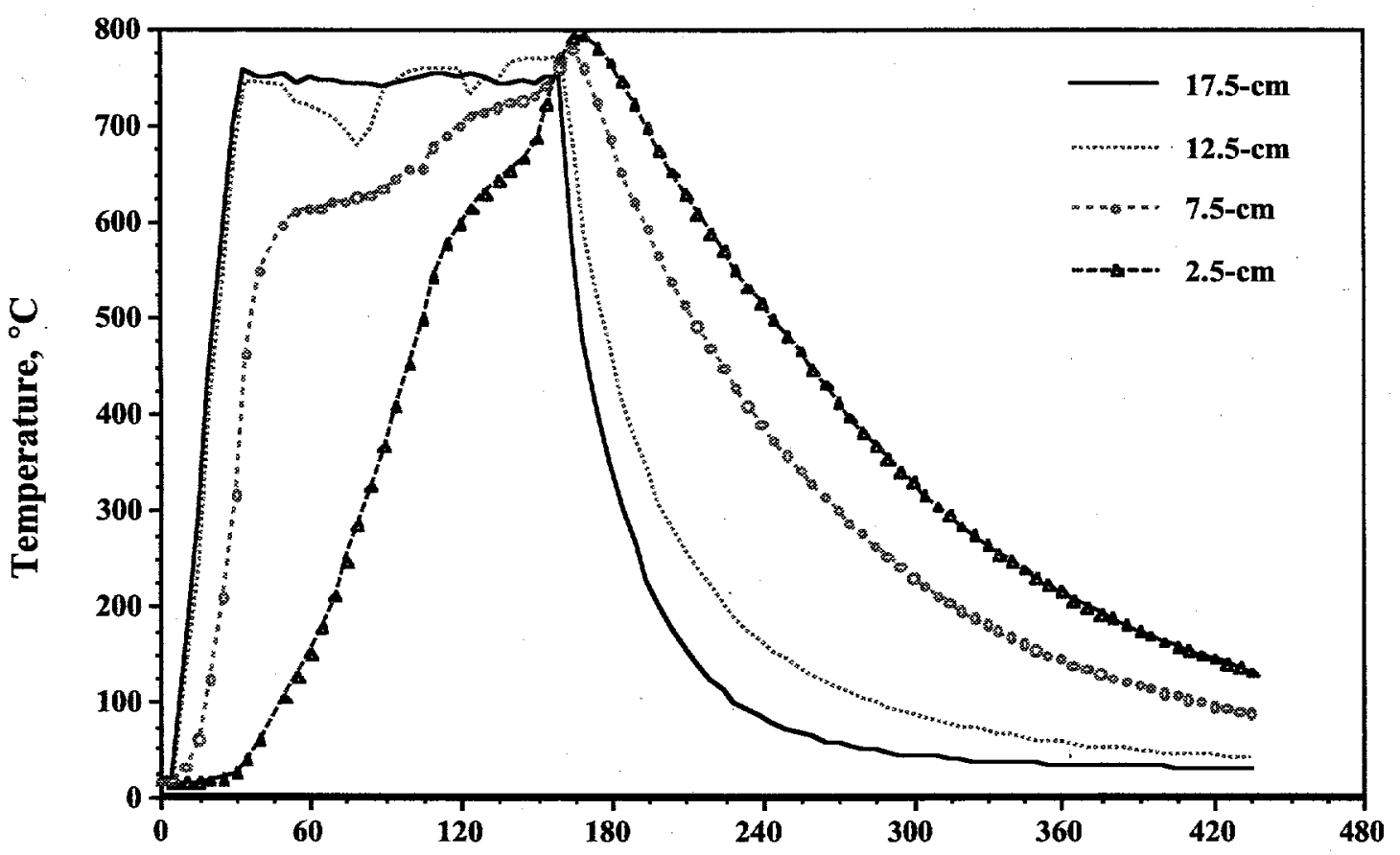

Time, minutes

Figure 3.6. Temperature Profile for Test \#8 - Uncalcined U of M Ash 
shown signs that volume expansion occurred during processing. The amount of cerium recovered for the three tests is

\author{
Test \#1 - $0.788 \mathrm{~g} \mathrm{Ce} / \mathrm{kg}$ final product \\ Test \#4 - $0.129 \mathrm{~g} \mathrm{Ce} / \mathrm{kg}$ final product \\ Test \#7 - $2.64 \mathrm{~g} \mathrm{Ce} / \mathrm{kg}$ final product
}

Using the criterion for plutonium of $15 \mathrm{~g} \mathrm{Pu} / \mathrm{kg}$ final product, the results for the tests with cerium show that the full-scale product passes, even in the test run in which volume expansion occurred during processing. As will be discussed in Sections 3.2.1 and 3.2.2, for the recoverability test, cerium, in the form of cerium oxide, is more easily recovered than plutonium.

\title{
3.2 Small-Scale Testing
}

A total of six small-scale $\mathrm{Pu}$-bearing ash vitrification tests were performed. The first two used a combination of RF Ash-1, $U$ of $M$ ash, and cerium oxide. The $U$ of $M$ ash was used to bring the ash loading content to above $35 \mathrm{wt} \%$. This was necessary because the Pu content of RF Ash-1 was $16 \mathrm{wt} \%$ and required an $8: 1$ dilution to get down to $2 \mathrm{wt} \%$ in the final product. Without the addition of the $U$ of $M$ ash, the ash loading would have been around $10 \mathrm{wt} \%$. The remaining four small-scale tests used the LANL-supplied incinerator ashes BASH1H and TDC193A. Table 3.2 provides a summary of the formulations and conditions used to vitrify the Pu-bearing ashes.

\subsubsection{Preparation and Performance of RF Ash-1 \#1}

For the RF Ash-1, the measured Pu content was $0.16 \mathrm{~g} \mathrm{Pu} / \mathrm{g}$ ash. For the weights shown in Table 3.1, this leads to a Pu content of $1.96 \mathrm{wt} \%$ in the final mixture. The ash mixture consisting of RF Ash-1, $\mathrm{U}$ of $\mathrm{M}$ ash, and $\mathrm{CeO}_{2}$ was calcined at $700^{\circ} \mathrm{C}$ for six hours. After calcination, the mixture was found to have lost $4.3 \mathrm{wt} \%$, which was less than the $5.4 \mathrm{wt} \%$ predicted based on the thermogravimetric analyses (TGA) of the RF Ash-1 and U of M ashes presented in Figures 3.7 and 3.8, respectively. After calcination, the treated ash mixture was mixed with glass frit and heated at $800^{\circ} \mathrm{C}$. This mixture foamed excessively, increasing its volume by at least $25 \%$ and reaching the top of the $600 \mathrm{~mL}$ stainless steel beaker (see Figure 3.9). The material in the beaker failed to subside after the beaker and contents were allowed to cool for 15 minutes before returning them to the $800^{\circ} \mathrm{C}$ furnace. The measured density of samples from the beaker was $1.8 \mathrm{~g} / \mathrm{cm}^{3}$. For reference, a fully vitrified sample typically has a density of $2.5 \mathrm{~g} / \mathrm{cm}^{3}$. 
Table 3.2. Summary of Small-Scale Ash Vitrification Tests

\begin{tabular}{|c|c|c|c|c|c|c|c|}
\hline Run Number & Ash Mixture & $\begin{array}{c}\text { Glass } \\
\text { Frit }\end{array}$ & $\begin{array}{c}\text { Final } \mathrm{Pu} \\
\text { Content, wt } \%\end{array}$ & $\begin{array}{l}\text { Ash Loading, } \\
\text { wt } \%\end{array}$ & $\begin{array}{l}\text { Pretreatment } \\
\text { Conditions }\end{array}$ & $\begin{array}{l}\text { Vitrification } \\
\text { Conditions }\end{array}$ & Observations \\
\hline RF Ash-1 \#1 & $\begin{array}{l}55 \mathrm{~g} \mathrm{RF} \text { ash-1 } \\
113 \mathrm{~g} \mathrm{U} \text { of } \mathrm{M} \\
16.2 \mathrm{~g} \mathrm{CeO}_{2}\end{array}$ & $265 \mathrm{~g}$ & 1.96 & 37.4 & $\begin{array}{l}\text { Calcined ash mixture } \\
\text { at } 700^{\circ} \mathrm{C} \text { for } 6 \text { hours }\end{array}$ & $\begin{array}{l}70 \text { min. at } \\
800^{\circ} \mathrm{C}\end{array}$ & $\begin{array}{l}\text { Expansion of } \\
25 \mathrm{vol} \% \text {; mass } \\
\text { loss }=4.3 \mathrm{wt} \%\end{array}$ \\
\hline RF Ash-1 \#2 & $\begin{array}{l}18 \mathrm{~g} \mathrm{RF} \text { ash-1(a) } \\
134 \mathrm{~g} \mathrm{U}^{(\mathrm{a}} \text { of } \\
5.8 \mathrm{~g} \mathrm{CeO}_{2}\end{array}$ & $237 \mathrm{~g}$ & 0.87 & 38.5 & $\begin{array}{l}\text { Ash and frit mixture } \\
\text { calcined at } 700^{\circ} \mathrm{C} \text { for } \\
1 \mathrm{hr}\end{array}$ & $\begin{array}{l}4.5 \mathrm{hr} \text { at } \\
800^{\circ} \mathrm{C}\end{array}$ & $\begin{array}{l}\text { Initial foaming of } \\
75 \mathrm{vol} \% \text {; net zero } \\
\text { change at end }\end{array}$ \\
\hline BASH1H \#1 & $68.6 \mathrm{~g} \mathrm{BASH} 1 \mathrm{H}$ & $314 \mathrm{~g}$ & 3.92 & 17.9 & $\begin{array}{l}\text { Calcined ash } 46 \mathrm{hr} \text { at } \\
700^{\circ} \mathrm{C}\end{array}$ & $\begin{array}{l}2.5 \mathrm{hr} \text { at } \\
800^{\circ} \mathrm{C}\end{array}$ & No foaming \\
\hline BASH1H \#2 & $65 \mathrm{~g} \mathrm{BASH} 1 \mathrm{H}$ & $65 \mathrm{~g}$ & 7.5 & 50.0 & None & $\begin{array}{l}2.5 \mathrm{hr} \text { at } \\
800^{\circ} \mathrm{C}\end{array}$ & Foamed $(40 \%)$ \\
\hline BASH1H \#3 & $65 \mathrm{~g}$ BASH1H & $65 \mathrm{~g}$ & 7.5 & 50.0 & $\begin{array}{l}1.3 \mathrm{hr} \text { at } 450^{\circ} \mathrm{C} \text {; } \\
\text { heated to } 800^{\circ} \mathrm{C} \\
\text { at } 5^{\circ} \mathrm{C} / \mathrm{min}\end{array}$ & $1 \mathrm{hr}$ at $800^{\circ} \mathrm{C}$ & $\begin{array}{l}\text { Remained powder } \\
\text { at } 450^{\circ} \mathrm{C} \text {; foamed } \\
(40 \%)\end{array}$ \\
\hline TDC193A & $86 \mathrm{~g}$ TDC193A & $329 \mathrm{~g}$ & 3.2 & 20.7 & $74 \mathrm{hr}$ at $700^{\circ} \mathrm{C}$ & $\begin{array}{l}2.5 \mathrm{hr} \text { at } \\
800^{\circ} \mathrm{C}\end{array}$ & No foaming \\
\hline
\end{tabular}




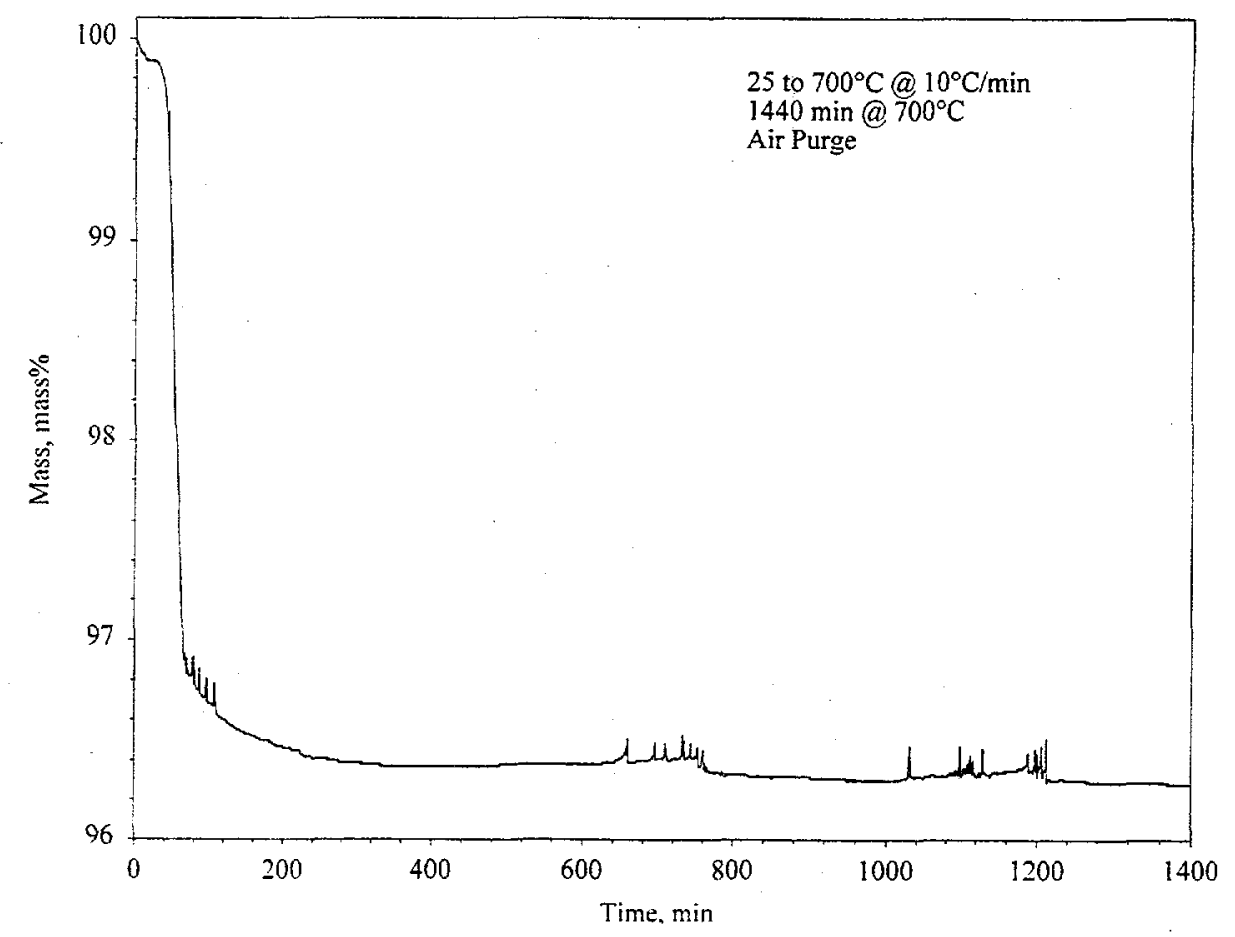

Figure 3.7. Thermal Behavior of $U$ of $M$ Ash as Measured by TGA. Sample heated to $700^{\circ} \mathrm{C}$ at $10^{\circ} \mathrm{C} / \mathrm{min}$ and held isothermally for 24 hours

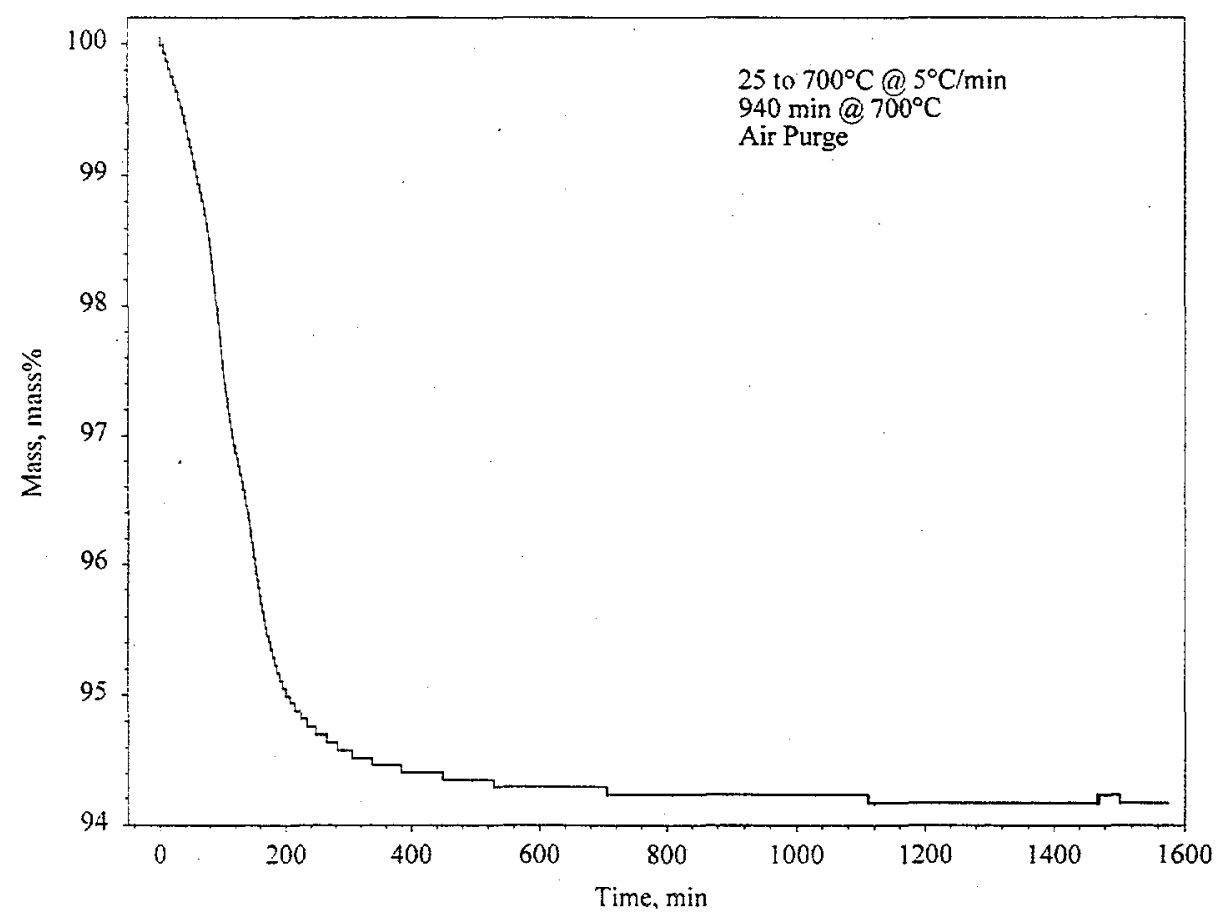

Figure 3.8. Thermal Behavior of RF Ash- 1 as Measured by TGA. Sample heated at $700^{\circ} \mathrm{C}$ at $5^{\circ} \mathrm{C} / \mathrm{min}$ and held isothermally for 15.7 hours 


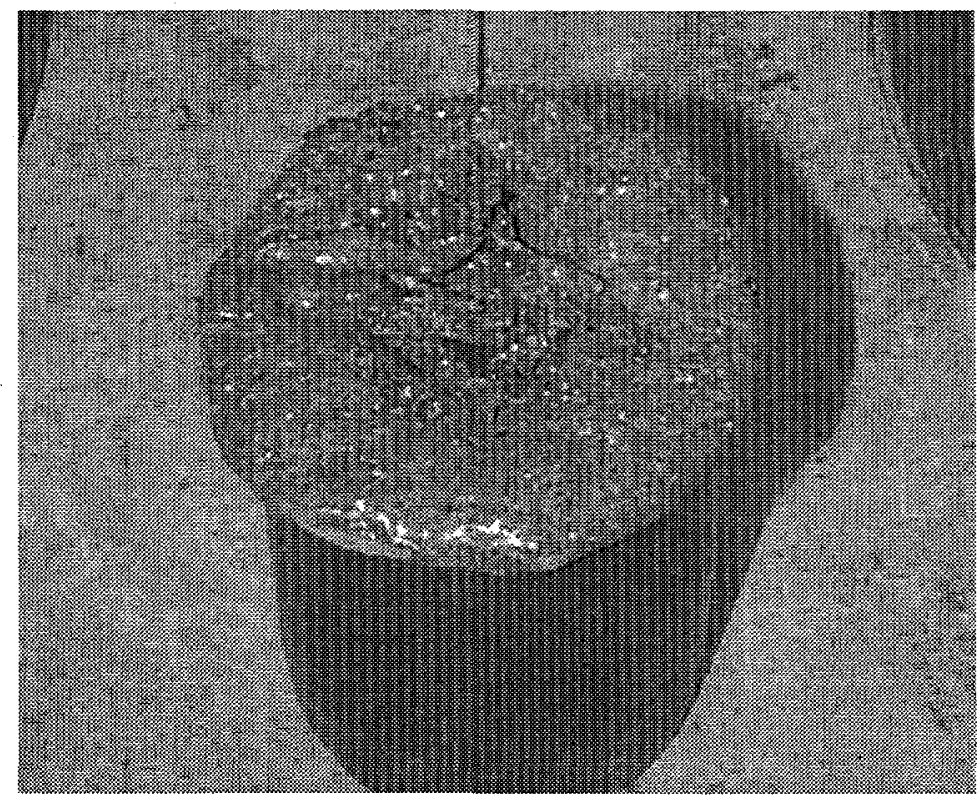

Figure 3.9. RF Ash-1 \#1 Final Product - Volume Expansion of $25 \%$

Based on the GEA and AEA analyses for plutonium and the ICP analysis for cerium, the processed ash and frit mixture contained $1.5 \mathrm{wt} \% \mathrm{Pu}$ and $3 \mathrm{wt} \% \mathrm{Ce}$. The $1.5 \mathrm{wt} \% \mathrm{Pu}$ is less than the estimated $2 \mathrm{wt} \%$, suggesting variability in the distribution of $\mathrm{Pu}$ in the RF Ash-1. The agreement of the measured cerium concentration with the calculated value suggests good mixing of cerium in the final product.

Assuming full recovery of any glass that overflowed the beaker as a result of the volume expansion, the glass lost $0.3 \mathrm{wt} \%$. Assuming this additional mass loss was due to residual carbon because of incomplete calcination, $0.14 \mathrm{~g}$-moles of carbon dioxide ( $3 \mathrm{~L}$ at standard temperature and pressure) would have formed. This is a significant volume of gas relative to the volume of material processed. Calcination for this test and the remaining tests was performed in a stainless steel beaker with very little mixing. More pretreatment time, or processing with good mixing and access to an oxygen source, at $700^{\circ} \mathrm{C}$ would remove this residual carbon material from the ash mixture.

Although the ash and frit mixture foamed during the vitrification process step, the final product still performed well in the recoverability test. Following the recoverability testing procedure in Section 2.3, the product from RF Ash-1 \#1 lost $1.2 \mathrm{~g} \mathrm{Pu} / \mathrm{kg}$ final product and $5 \mathrm{~g} \mathrm{Ce} / \mathrm{kg}$ final product. Both of these values are below the acceptability criterion of $15 \mathrm{~g} \mathrm{Pu} / \mathrm{kg}$ final product (Luey et al. 1998). The amount recovered corresponds to $6.1 \%$ and $16 \%$ of the original amount of $\mathrm{Pu}$ and $\mathrm{Ce}$, respectively. The recoverability data also show that cerium oxide is a conservative surrogate for plutonium in terms of recoverability. One potential reason for this is the fact that the $\mathrm{Pu}$ may be bound to ash particles, while the cerium in the original mixture is free as an oxide. 


\subsubsection{Preparation and Performance of RF Ash-1 \#2}

Because of a limited amount of RF Ash-1 available for a second test, the ash loading was targeted to be $40 \mathrm{wt} \%$ ash with the $U$ of $M$ ash used as additional material. With this ash loading, the target final $\mathrm{Pu}$ and $\mathrm{Ce}$ contents were $0.8 \mathrm{wt} \%$ and $1.2 \mathrm{wt} \%$, respectively. For this test, the ash mixture and glass frit were combined prior to calcination. The purpose of this was to simulate previous conditions tested using ash surrogate materials (Luey et al. 1998). Calcination of the mixture was performed at $700^{\circ} \mathrm{C}$ for one hour, resulting in loss of $0.7 \mathrm{wt} \%$ (note that the $\mathrm{RF}$ Ash-1 used had been previously calcined while the $U$ of $M$ ash had not).

After calcination, the ash and frit mixture was processed at $800^{\circ} \mathrm{C}$ for 30 minutes, during which time the mixture foamed $80 \%$. The beaker was removed from the furnace and allowed to cool for 15 minutes. The beaker was returned to the $800^{\circ} \mathrm{C}$ furnace. After three hours, the volume had subsided back to its original level (see Figure 3.10). The density of samples of the final product was $2.1 \mathrm{~g} / \mathrm{cm}^{3}$. Based on the analyses for $\mathrm{Pu}$ and $\mathrm{Ce}$, the final product contained $0.87 \mathrm{wt} \% \mathrm{Pu}$ and $1.3 \mathrm{wt} \% \mathrm{Ce}$.

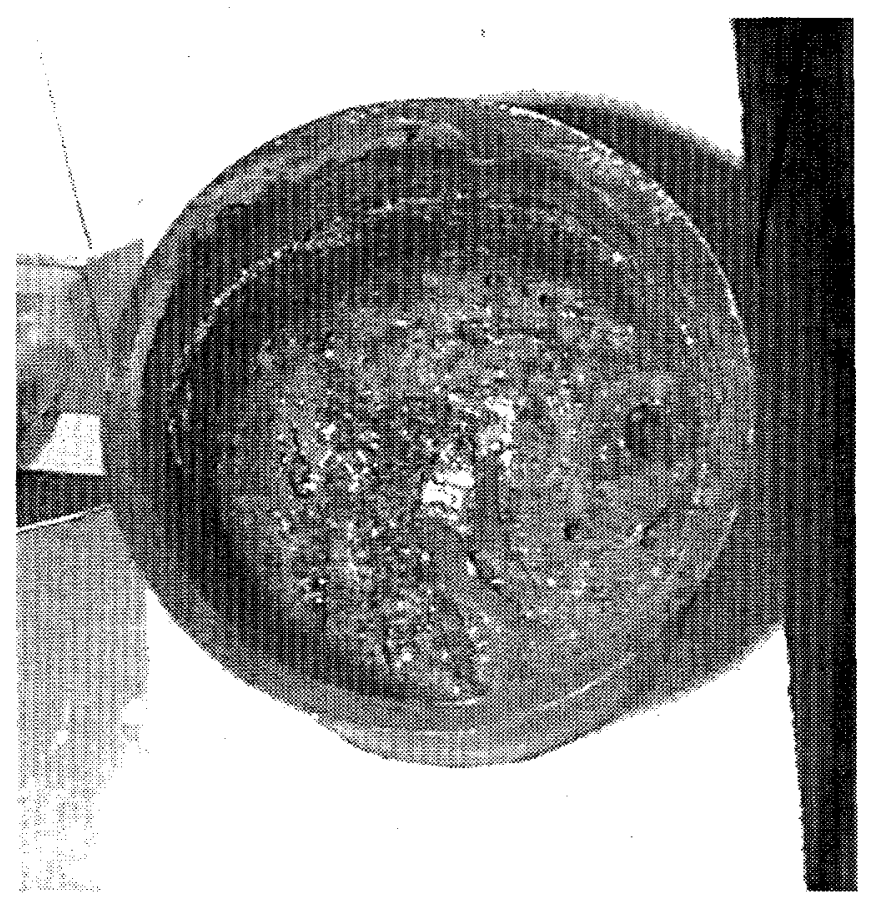

Figure 3.10. RF Ash-1 \#2 - Final Product After Foaming and Subsidence 
The combined mass loss from the calcination and vitrification operations was $6.7 \mathrm{wt} \%$, slightly less than the mass loss predicted by the $U$ of $M$ ash TGA presented in Figure 3.7; no mass loss would be expected from the previously calcined RF Ash-1. Assuming additional mass loss was all from the oxidation of residual carbon, $0.6 \mathrm{~g}$-moles of $\mathrm{CO}_{2}(13 \mathrm{~L}$ at standard temperature and pressure) would have been released. Pretreatment of the $\mathrm{U}$ of $\mathrm{M}$ ash to remove all residual carbon would have eliminated foaming during vitrification (this is supported by the full-scale work performed with calcined ash surrogates).

The final product from the RF Ash-1 \#2 run performed very well in the recoverability test. About $11 \%$ of the original $\mathrm{Pu}$ was recovered, giving a recovered value of $1.2 \mathrm{~g} \mathrm{Pu} / \mathrm{kg}$ final product. For the cerium, $23 \%$ of the original was recovered, which corresponds to $3 \mathrm{~g} \mathrm{Ce} / \mathrm{kg}$ final product. The fraction of the original material recovered was higher than for the RF Ash-1 \#1 run; however, the recovered values per kilogram of final product were the same or lower. As seen previously, the fraction of cerium recovered was higher than for plutonium.

\subsubsection{Preparation and Performance of BASH1H \#1}

The objective for this run was to thoroughly pretreat the incinerator ash sample obtained from LANL to prevent foaming during the vitrification step. Calcination was performed at $700^{\circ} \mathrm{C}$ inside of a muffle furnace with periodic mixing.

Based on a 24-hour isothermal TGA of the BASH1H ash (see Figure 3.11), calcination of the ash sample was planned for 24 hours. Approximately $200 \mathrm{~g}$ of ash was placed into a $600-\mathrm{mL}$ stainless steel beaker and heated in the muffle furnace. After processing for 10.5 hours, the ash was observed to have hard white chunks on the surface. The beaker appeared corroded with a white scale on its outer surface and a reddish-orange coating on the inner surface. The sample had only lost $17.6 \mathrm{wt} \%$ out of the projected $28 \mathrm{wt} \%$ from the TGA curve.

Because this corrosive behavior had not been observed with the RF Ash-1 ash, nor with any of the nonradioactive surrogate ashes, a new $100 \mathrm{~g}$ batch of BASH1H was calcined in a ceramic crucible. After 20 hours, the batch had lost $26 \mathrm{wt} \%$ and did not exhibit any of the previously observed behavior. An additional 20 hours at $700^{\circ} \mathrm{C}$ released another $0.4 \mathrm{wt} \%$, bringing the total mass loss to $26.4 \mathrm{wt} \%$. Figure 3.12 shows the TGA, differential thermal analysis (DTA), and differential TGA (DTG) for the calcined BASH1H sample.

After archiving $5 \mathrm{~g}$ of the calcined ash, the remaining $68.6 \mathrm{~g}$ of material was combined with $314 \mathrm{~g}$ of glass frit. The mixture was processed at $800^{\circ} \mathrm{C}$ for 2.5 hours. No volume expansion was observed. The density of the final product was $2.35 \mathrm{~g} / \mathrm{cm}^{3}$, which indicates that some densification occurred as a result of thermal processing. The absence of foaming is consistent with the lack of discernable mass loss shown in the TGA curve in Figure 3.12. A photo of the final product is shown in Figure 3.13. 


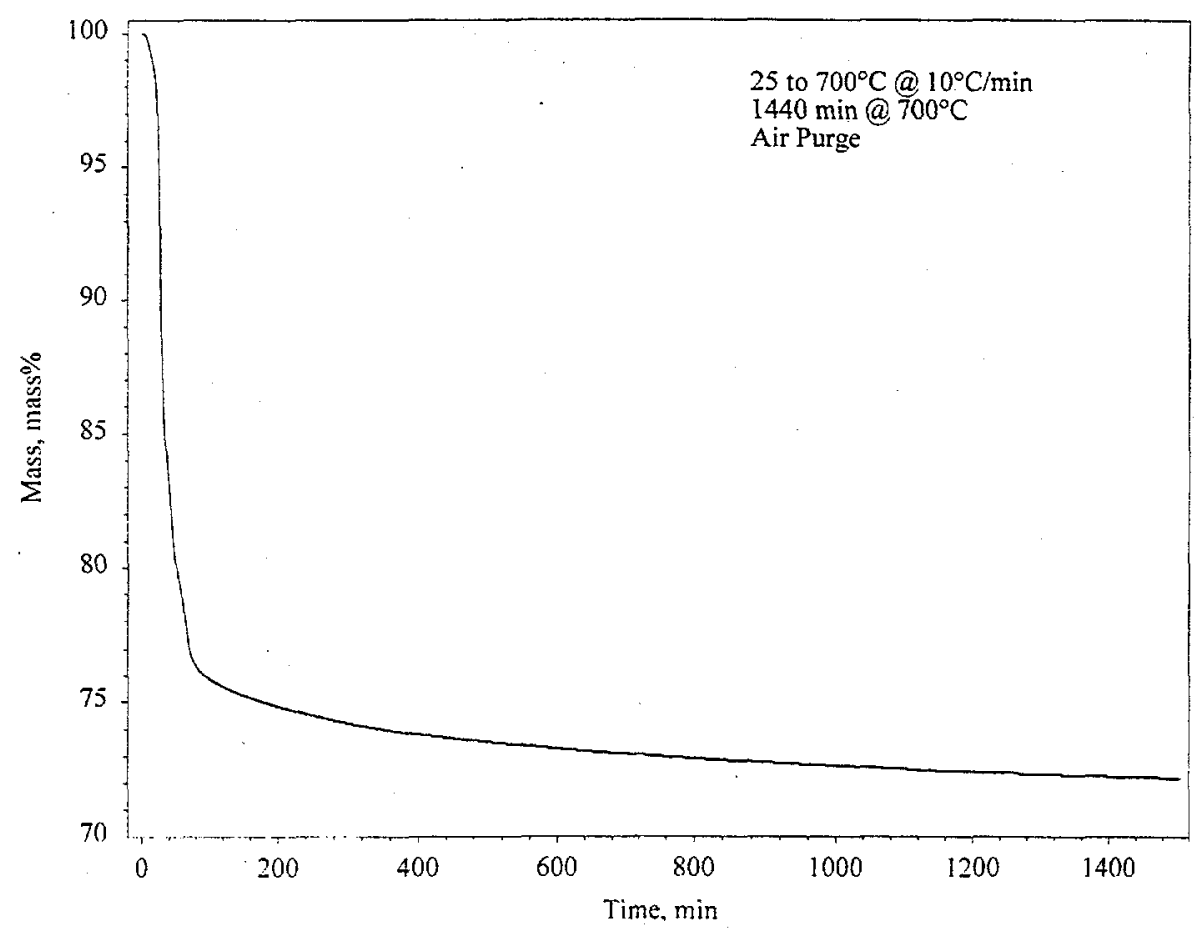

Figure 3.11. Thermal Behavior of RF BASH1H as Measured by TGA. Sample heated at $700^{\circ} \mathrm{C}$ at $5^{\circ} \mathrm{C} / \mathrm{min}$ and held isothermally for 24 hours.

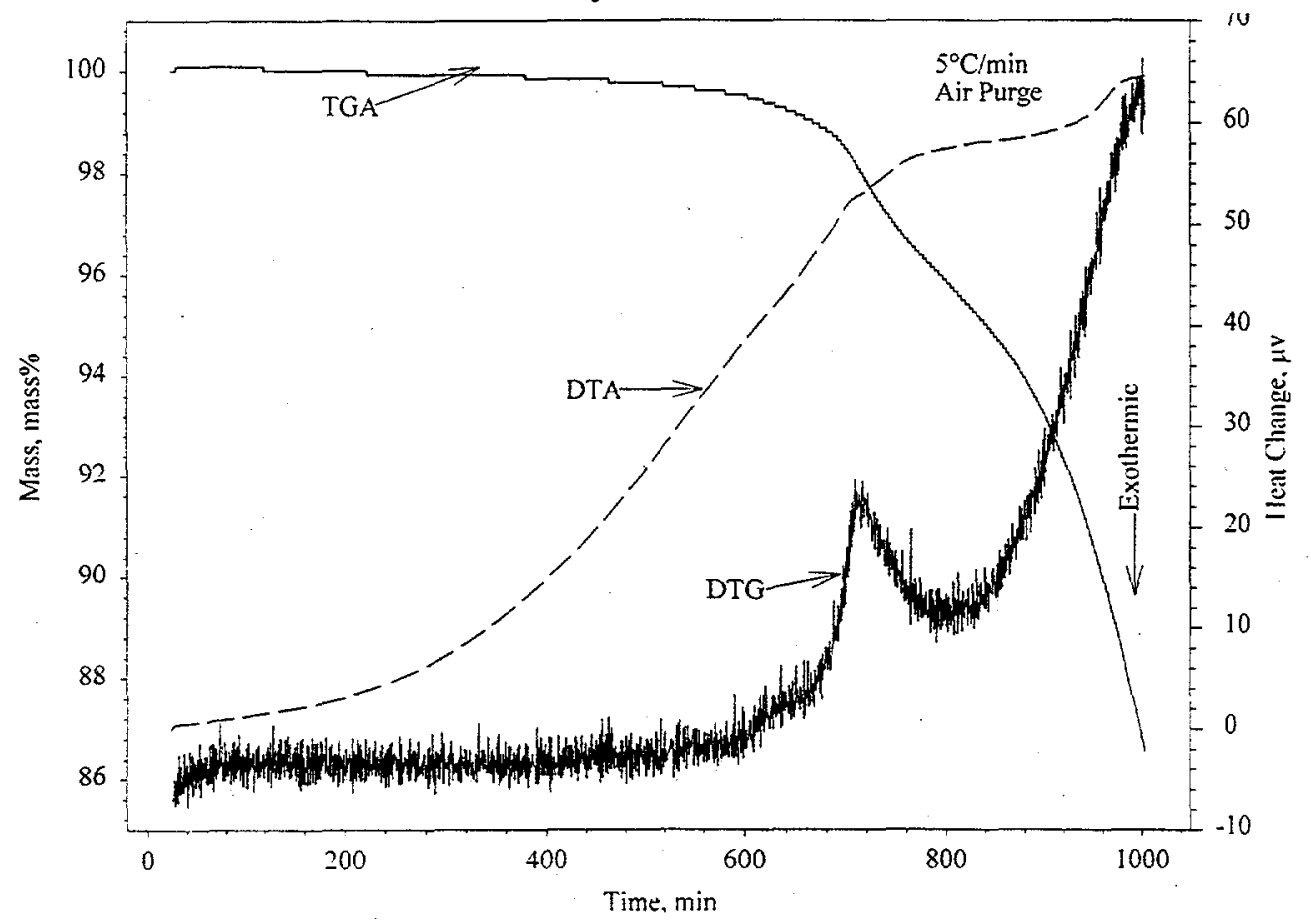

Figure 3.12. Thermal Behavior of Calcined BASH1H as Measured by TGA and DTA at $5^{\circ} \mathrm{C} / \mathrm{min}$ 


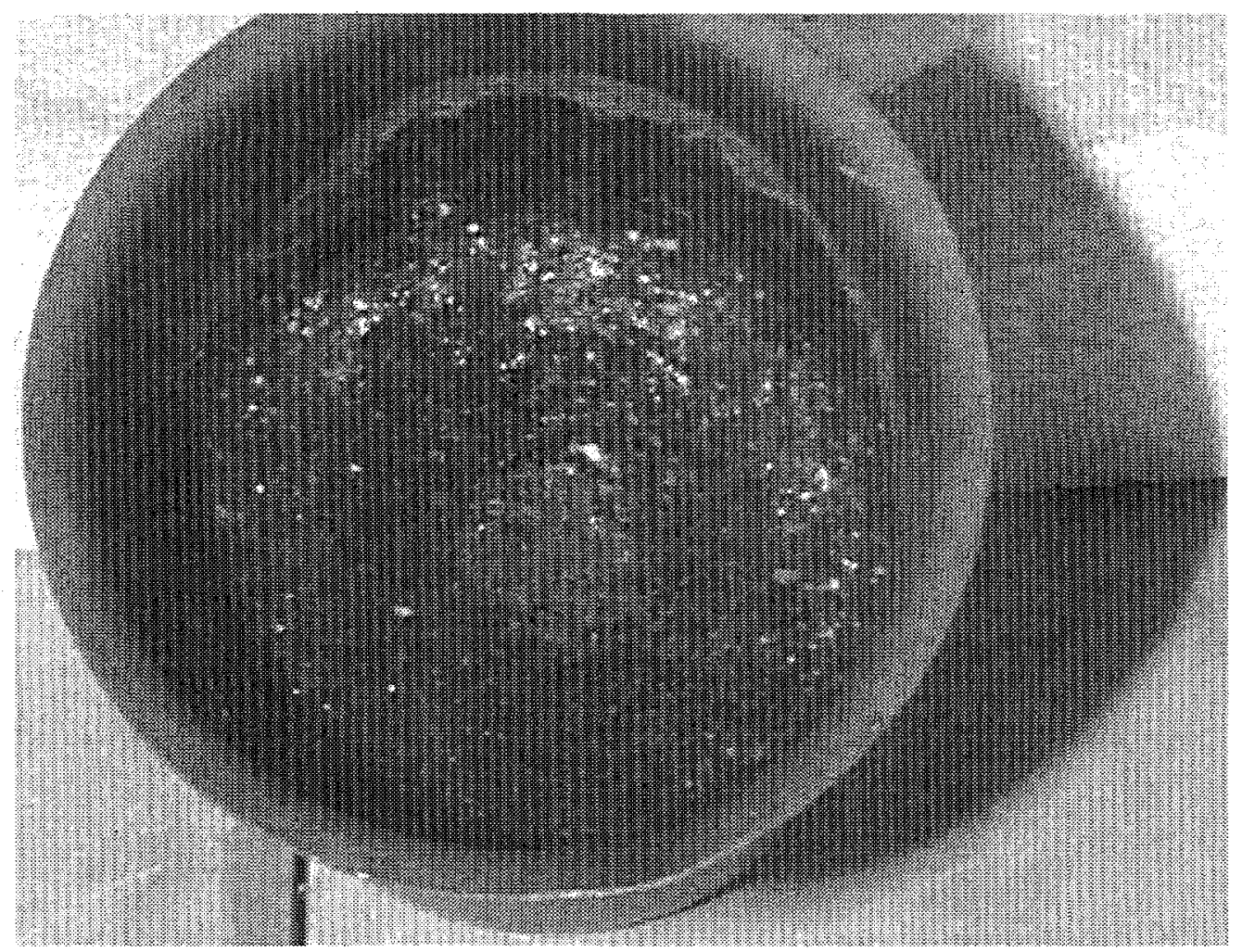

Figure 3.13. Final Product from BASH1H \#1

Based on the AEA analysis of combined $239 \mathrm{Pu}$ and $240 \mathrm{Pu}$ and the isotopic data provided by LANL, the final product contained $4.2 \mathrm{wt} \% \mathrm{Pu}$. Based on the $0.15 \mathrm{~g} \mathrm{Pu} / \mathrm{g}$ ash level determined by nondestructive assay (NDA) at LANL and using the original mass of ash used, the predicted $\mathrm{Pu}$ content in the final product was $3.92 \mathrm{wt} \%$. For the recoverability test, $6 \mathrm{~g} \mathrm{Pu} / \mathrm{kg}$ final product was recovered, corresponding to $13 \%$ of the original $\mathrm{Pu}$ in the sample. Even with a Pu loading twice that used for the RF Ash-1 tests, the final product was below the recoverability limit of $15 \mathrm{~g} \mathrm{Pu} / \mathrm{kg}$ product.

\subsubsection{Preparation and Performance of BASH1H \#2 and \#3}

The purpose of runs \#2 and \#3 with BASH1H was to evaluate the other two pretreatment options: 1) do not pretreat the ash and 2) pretreat the ash and glass frit mixture at the same time. For both options, $65 \mathrm{~g}$ of as-received BASH1H ash was mixed with $65 \mathrm{~g}$ of glass frit.

For run $\# 2$, the ash and glass frit mixture was immediately placed into a furnace heated to $800^{\circ} \mathrm{C}$. After the first 30 minutes, there was slight foaming observed. After an additional 30 minutes, the batch volume had increased $40 \%$. During the remaining 1.5 hours of the test, the volume did not increase further, nor did it subside as it cooled to room temperature. The recoverability test 
resulted in $32 \%$ of the original material being leached from the product, which corresponds to a level of $18 \mathrm{~g} \mathrm{Pu} / \mathrm{kg}$ final product. This is above the $15 \mathrm{~g} \mathrm{Pu} / \mathrm{kg}$ final product allowed for the ash material. Comparing Figure 3.13 with Figure 3.14 shows the degree of foaming for BASH1H \#2 relative to the densified product of BASH1H \#1.

For run \#3, the ash and glass frit mixture was heated from room temperature to $450^{\circ} \mathrm{C}$ at $10^{\circ} \mathrm{C} / \mathrm{min}$ and held at $450^{\circ} \mathrm{C}$ for 1.3 hours. The mixture was not stirred during this pretreatment step. After pretreatment at $450^{\circ} \mathrm{C}$, the mixture was heated to $800^{\circ} \mathrm{C}$ at $5^{\circ} \mathrm{C} /$ minute and held at $800^{\circ} \mathrm{C}$ for one hour. As the TGA curve shown in Figure 3.15 illustrates, most of the mass loss occurs around $450^{\circ} \mathrm{C}$. This suggests that a low temperature treatment could effectively remove the volatiles from BASH1H. However, there are benefits from processing at higher temperatures, such as reduced processing time (Luey et al. 1999).

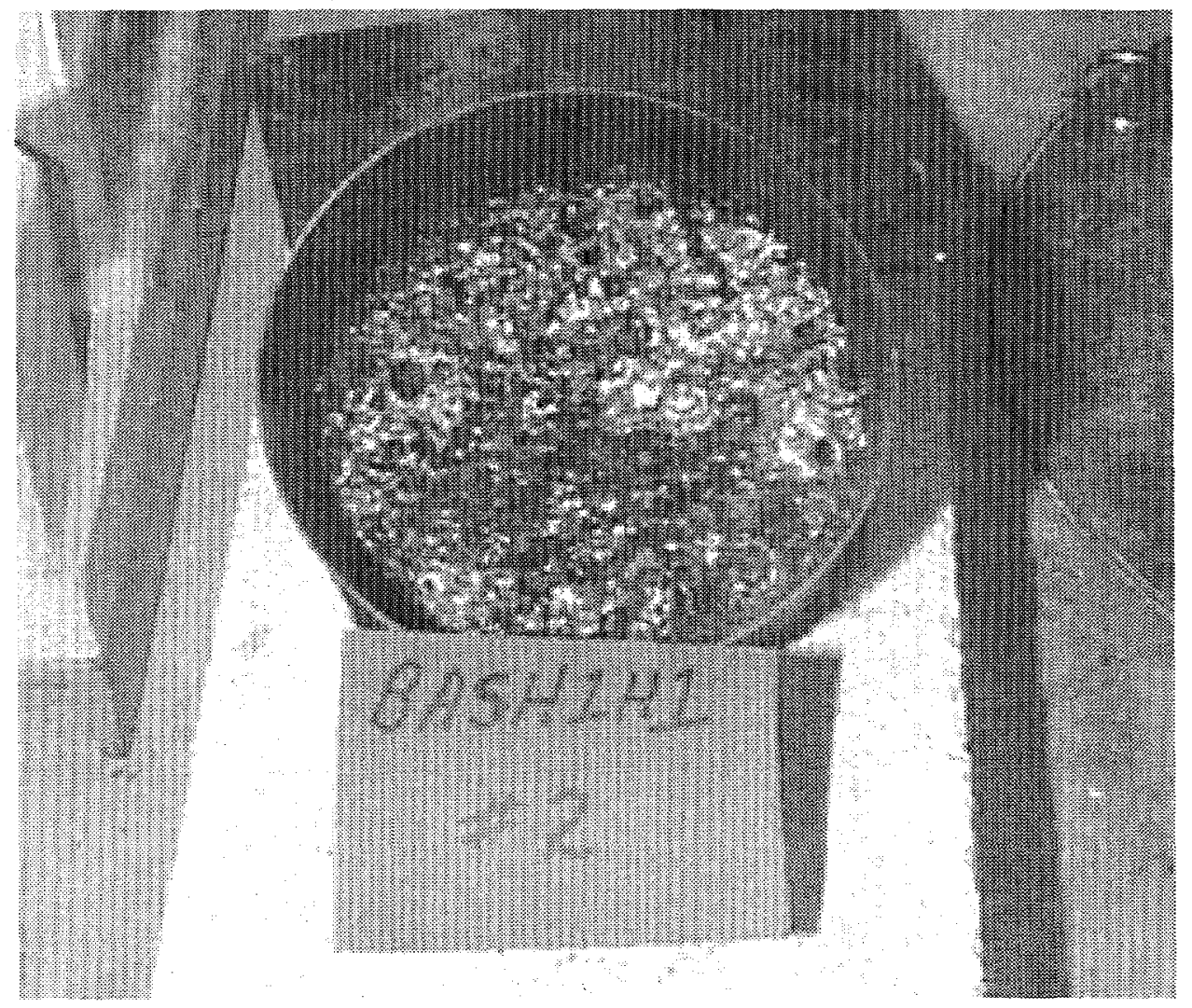

Figure 3.14. Final Product from $\mathrm{BASH} 1 \mathrm{H} \# 2$ 


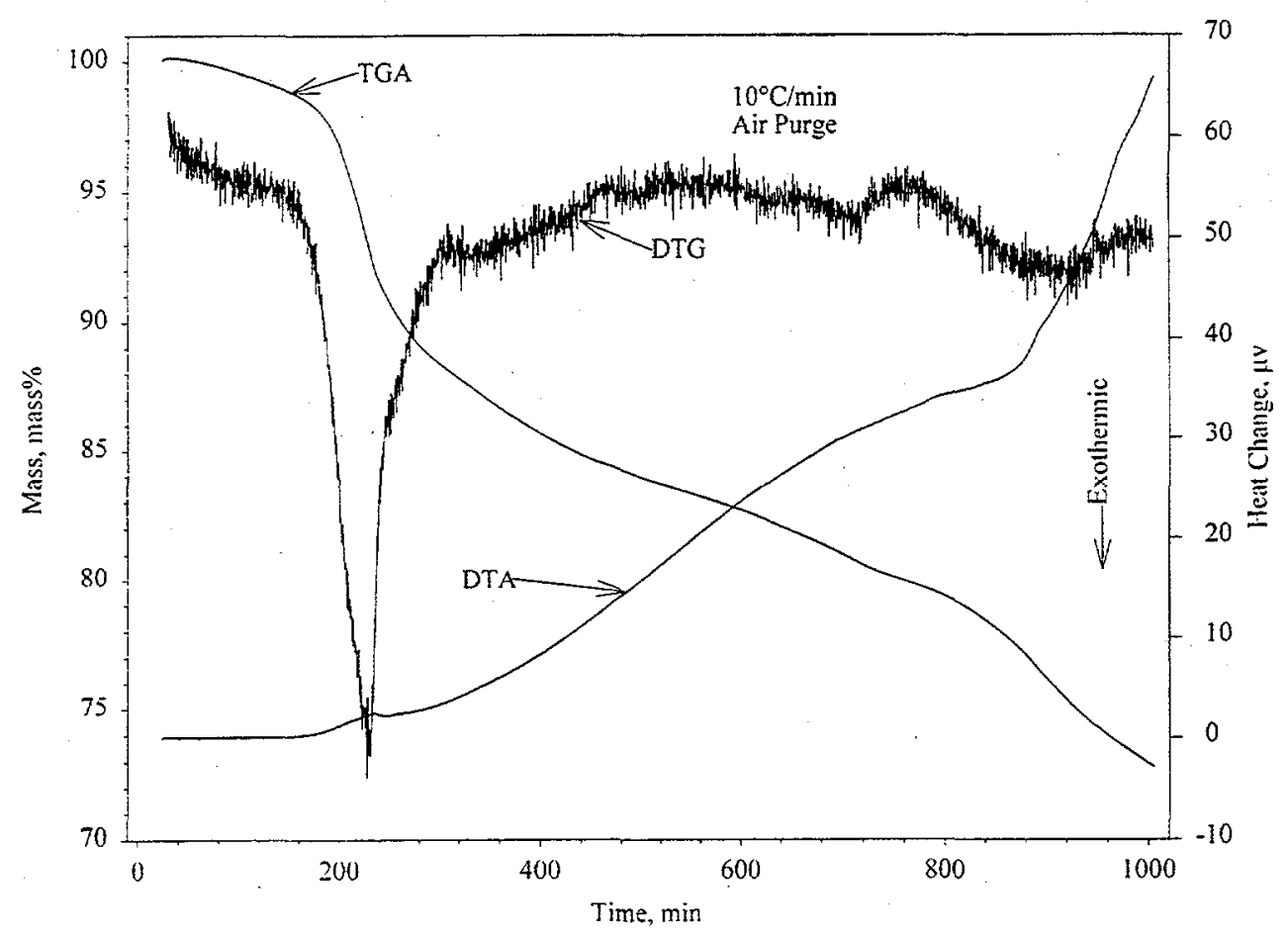

Figure 3.15. Thermal Behavior of As-Received BASH1H as Measured by TGA and DTA at $10^{\circ} \mathrm{C} / \mathrm{min}$

The ash and glass frit mixture remained unchanged (I.e., it stayed a powder) after processing at $450^{\circ} \mathrm{C}$. After 15 minutes at $800^{\circ} \mathrm{C}$, the mixture had foamed, increasing in volume by about $40 \%$. The glass volume did not increase further during the remaining 45 minutes at $800^{\circ} \mathrm{C}$, nor did it subside as it cooled to room temperature. The recoverability test resulted in $22 \%$ of the original Pu material being leached from the product, which corresponds to a level of $12 \mathrm{~g} \mathrm{Pu} / \mathrm{kg}$ final product. The improved performance of BASH1H \#3 in the recoverability test indicates that even moderate pretreatment can improve quality of the final product with respect to the recoverability criteria. Full pretreatment is necessary to minimize and/or eliminate process upsets (e.g., volume expansion of the ash and glass frit mixture) during vitrification.

\subsubsection{Preparation and Performance of TDC193A \#1}

A single test was performed using the LANL-supplied TDC193A incinerator ash. Based on the LANL NDA data, the incinerator ash contained $0.066 \mathrm{~g} \mathrm{Pu} / \mathrm{g}$ ash. The ash was stepwise calcined to remove residual carbon. Based on the TGA curve shown in Figure 3.16, it was predicted that calcining at $700^{\circ} \mathrm{C}$ in air would remove $66 \mathrm{wt} \%$ of the TDC193A's original mass, with $99 \%$ of the volatile combustion product lost after six hours. 


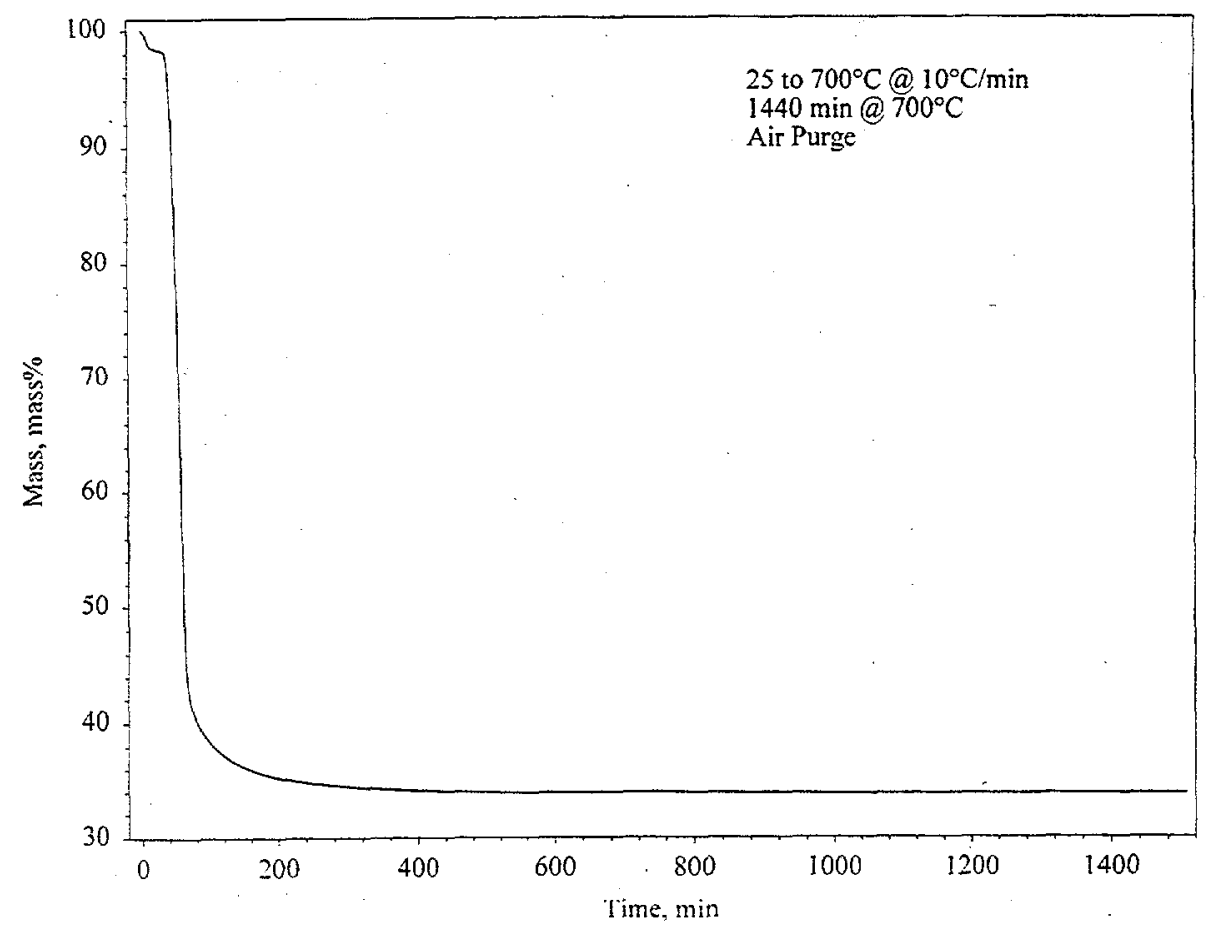

Figure 3.16. Thermal Behavior of TDC193A Incinerator Ash as Measured by TGA (heated to $700^{\circ} \mathrm{C}$ at $10^{\circ} \mathrm{C} / \mathrm{min}$ and held isothermally for 24 hours)

For the calcination step, a portion of the ash was calcined for several hours at $700^{\circ} \mathrm{C}$ in a porcelain crucible to reduce its volume enough for more material to be added. This was performed a number of times until the complete ash sample was calcined. After $260 \mathrm{~g}$ (out of $700 \mathrm{~g}$ ) of ash had been calcined, the crucible was found to have fractured along the calcined ash's surface line. A glass-like material was observed on the surface of the calcined material. This material was crushed, placed into a new ceramic crucible, and the calcination restarted.

For the vitrification test, $86 \mathrm{~g}$ of calcined ash was mixed with $329 \mathrm{~g}$ of glass frit. The ash and frit mixture was processed at $800^{\circ} \mathrm{C}$ for 2.5 hours. A mass loss of $2 \mathrm{~g}$ was observed, but no foaming occurred during the test. Figure 3.17 shows the final product. The density of the final product was $2.51 \mathrm{~g} / \mathrm{cm}^{3}$.

Based on the AEA analyses of combined $239 \mathrm{Pu}$ and $240 \mathrm{Pu}$, and the plutonium isotopics provided by LANL, the final product contained $3.0 \mathrm{wt} \% \mathrm{Pu}$. Based on the original $\mathrm{Pu}$ concentration of the ash, the predicted Pu content was $3.2 \mathrm{wt} \%$. The recoverability test removed $24 \%$ of the original material, which corresponds to a recovered amount of $6 \mathrm{~g} \mathrm{Pu} / \mathrm{kg}$ final product. This level is significantly below the upper limit of $15 \mathrm{~g} \mathrm{Pu} / \mathrm{kg}$ final product. 


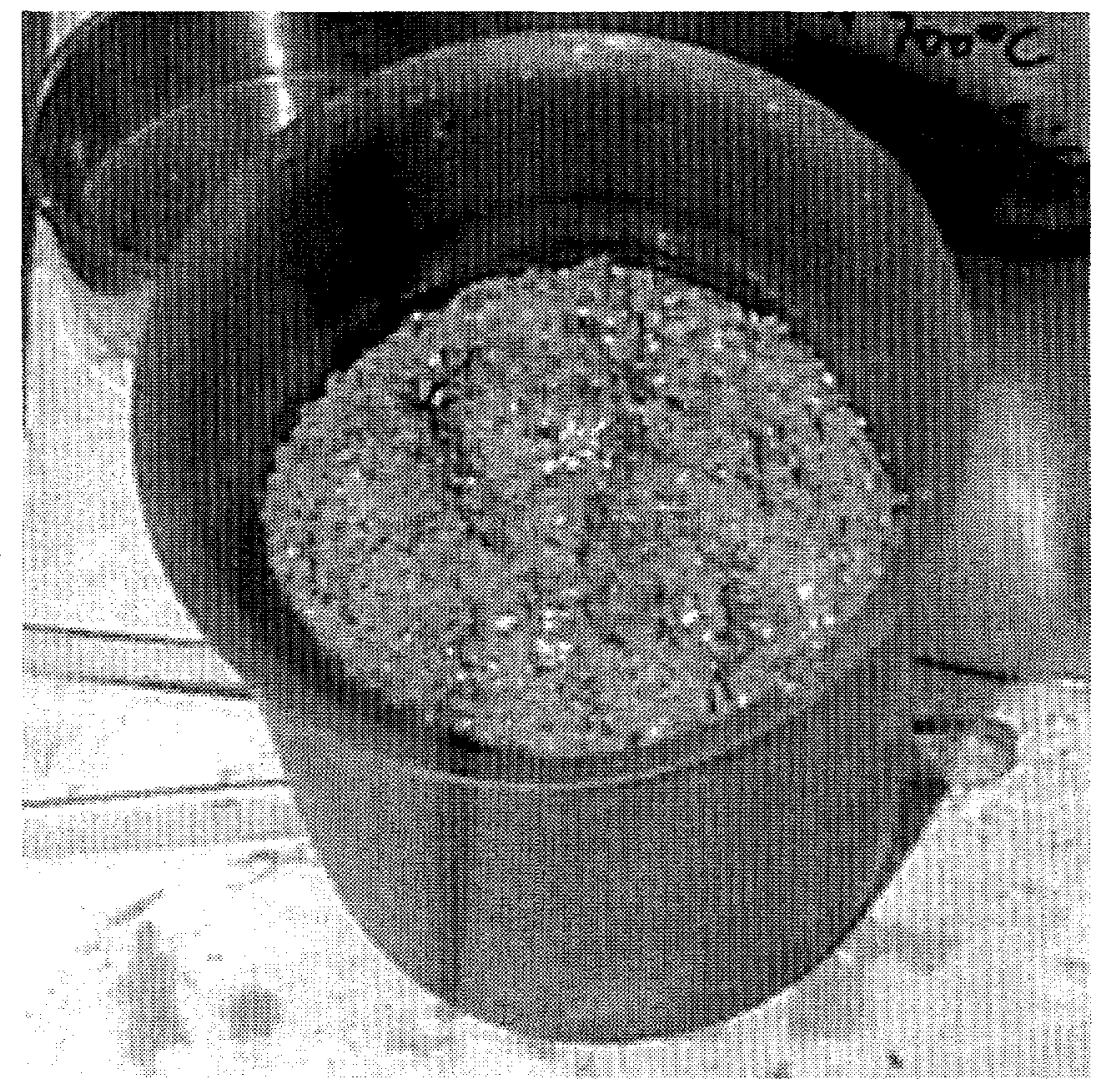

Figure 3.17. Final Product for TDC193A \#1 


\subsection{References}

Christiansen EL and WJ Maraman. 1969. Plutonium Processing at Los Alamos Scientific Laboratory. LA-3542, University of California - Berkeley, Berkeley, California.

Luey J, JD Vienna, H Li, and HL Wigent. 1998. Vitrification Process Option for Rocky Flats Incinerator Ash. PNNL-11770, Pacific Northwest National Laboratory, Richland, Washington.

Luey J, JG Darab, TS Autrey, JD Vienna, and HL Wigent. 1999. Characterization of Offgas Generated During Calcination Testing of Ash Surrogates. PNNL-11982, Pacific Northwest National Laboratory, Richland, Washington.

U.S. Environmental Protection Agency. 1992. Test Methods for Evaluating Solid Waste, Physical/Chemical Methods. SW-846, 3rd Edition, U.S. Environmental Protection Agency, Washington, D.C.

Vienna JD, H Li, JG Darab, P Hrma, J Luey, and ML Elliott. 1997. Frit Screening for Rocky Flats Ash and Sand, Slag, and Crucible Vitrification. PNNL-11591, Pacific Northwest National Laboratory, Richland, Washington.

Vienna JD, J Luey, P Hrma, DE Smith, RD Scheele, H Li, and HL Wigent. 1998. "Glass Frit Development for Encapsulation of Rocky Flats Ash." In Ceramic Transactions Volume 93: Environmental Issues and Waste Management Technologies in the Ceramic and Nuclear Industries IV. The American Ceramic Society.

Ziegler DL, JW Lindsay, and JK Fraser. 1971. Evaluation of Methods to Recover Plutonium from Incinerator Ash. RFP-1723, Dow Chemical Company, Rocky Flats Division, Golden, Colorado. 
Appendix

Temperature Profiles for Full-Scale Nonradioactive Tests 


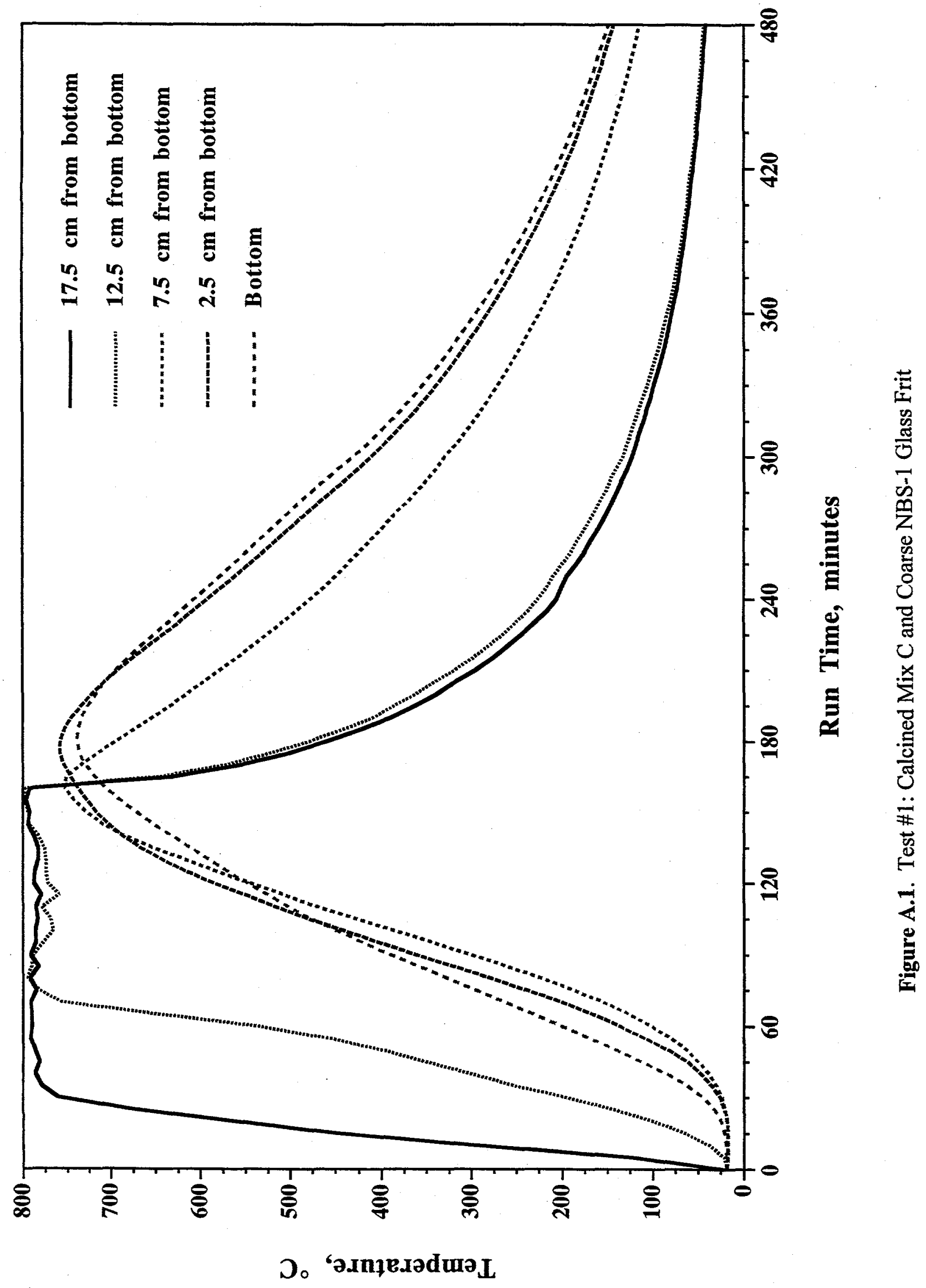

A. 1 


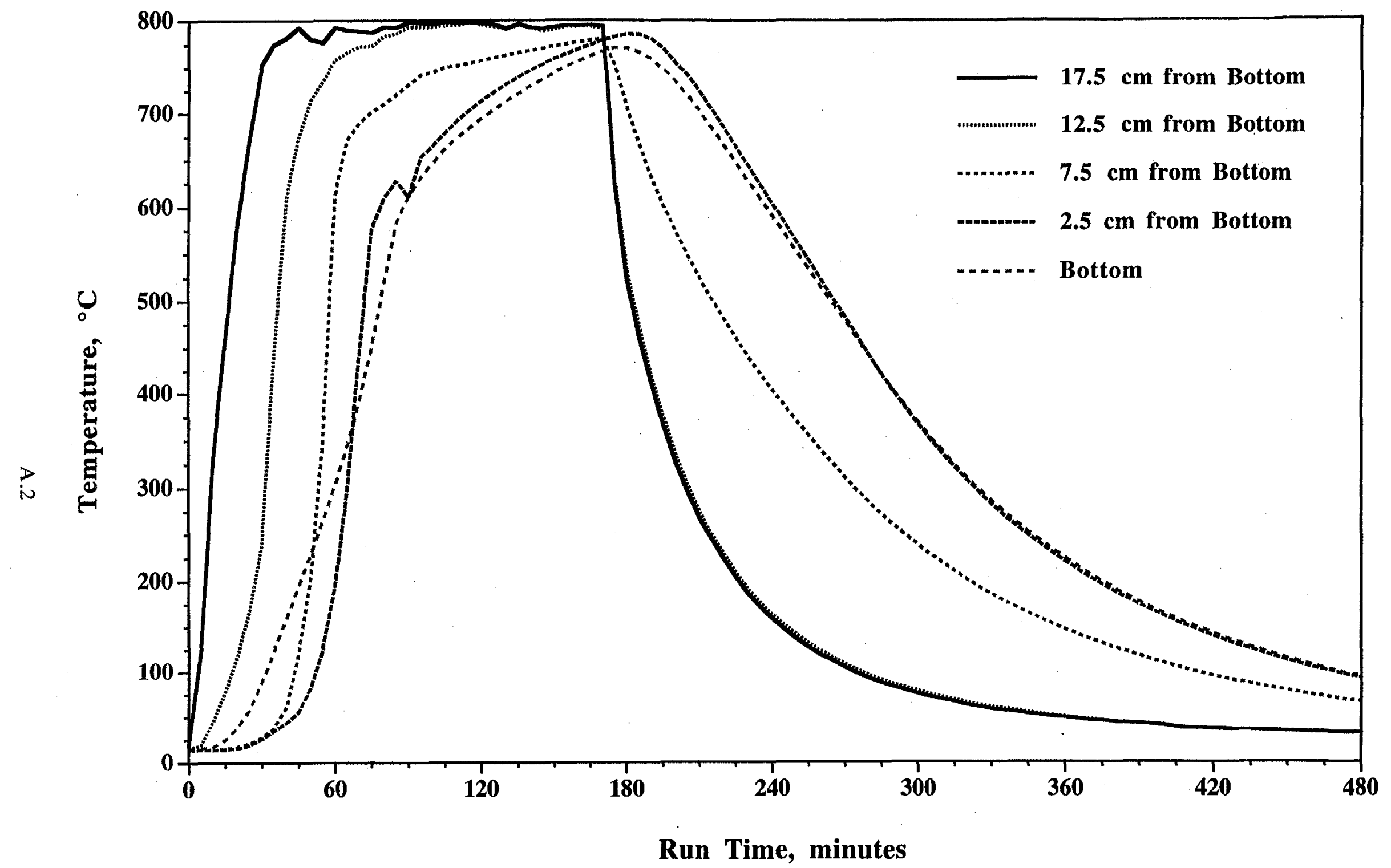

Figure A.2. Test \#2: Calcined Mix C and Fine NBS-1 Glass Frit 


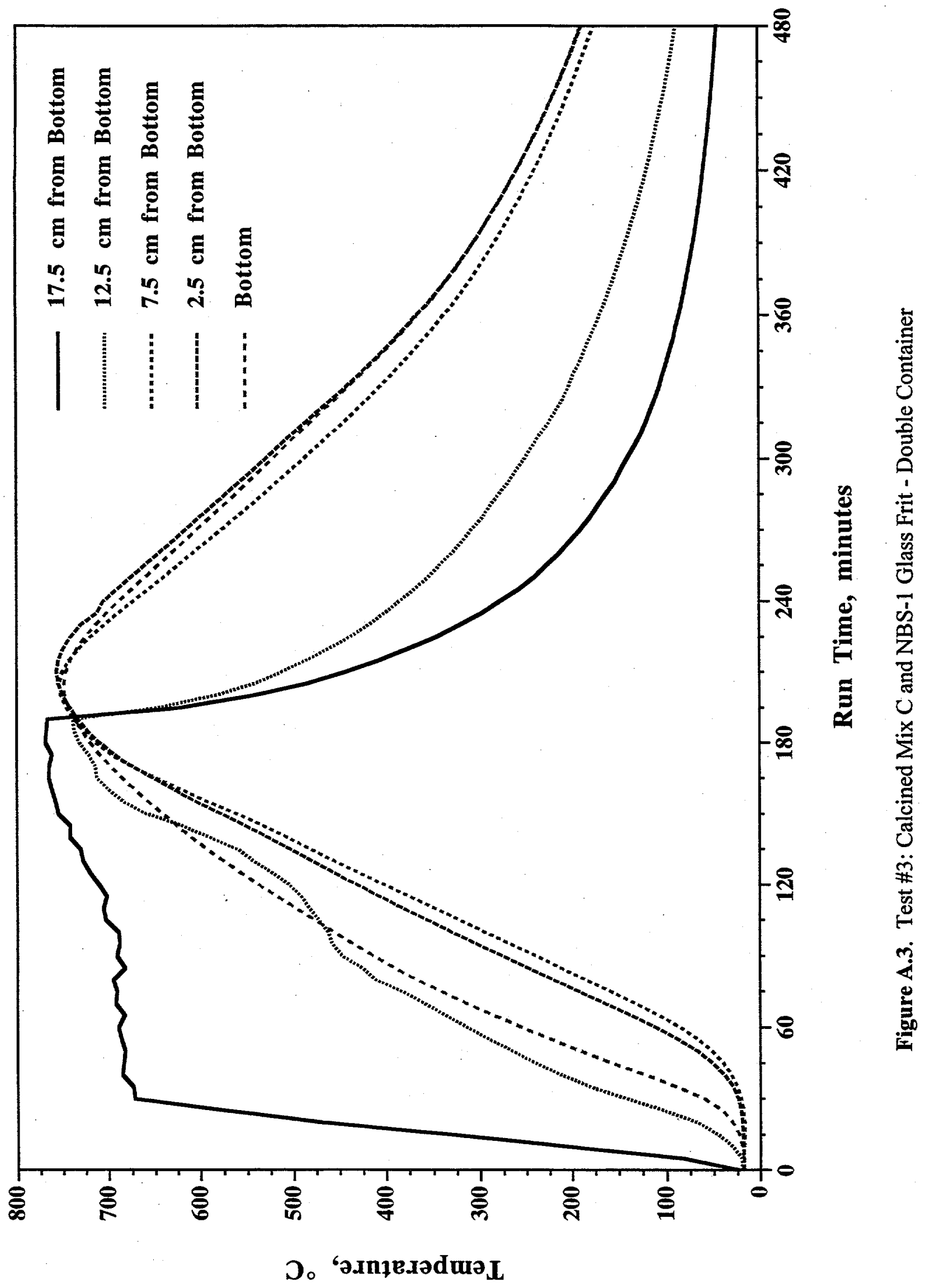

A. 3 


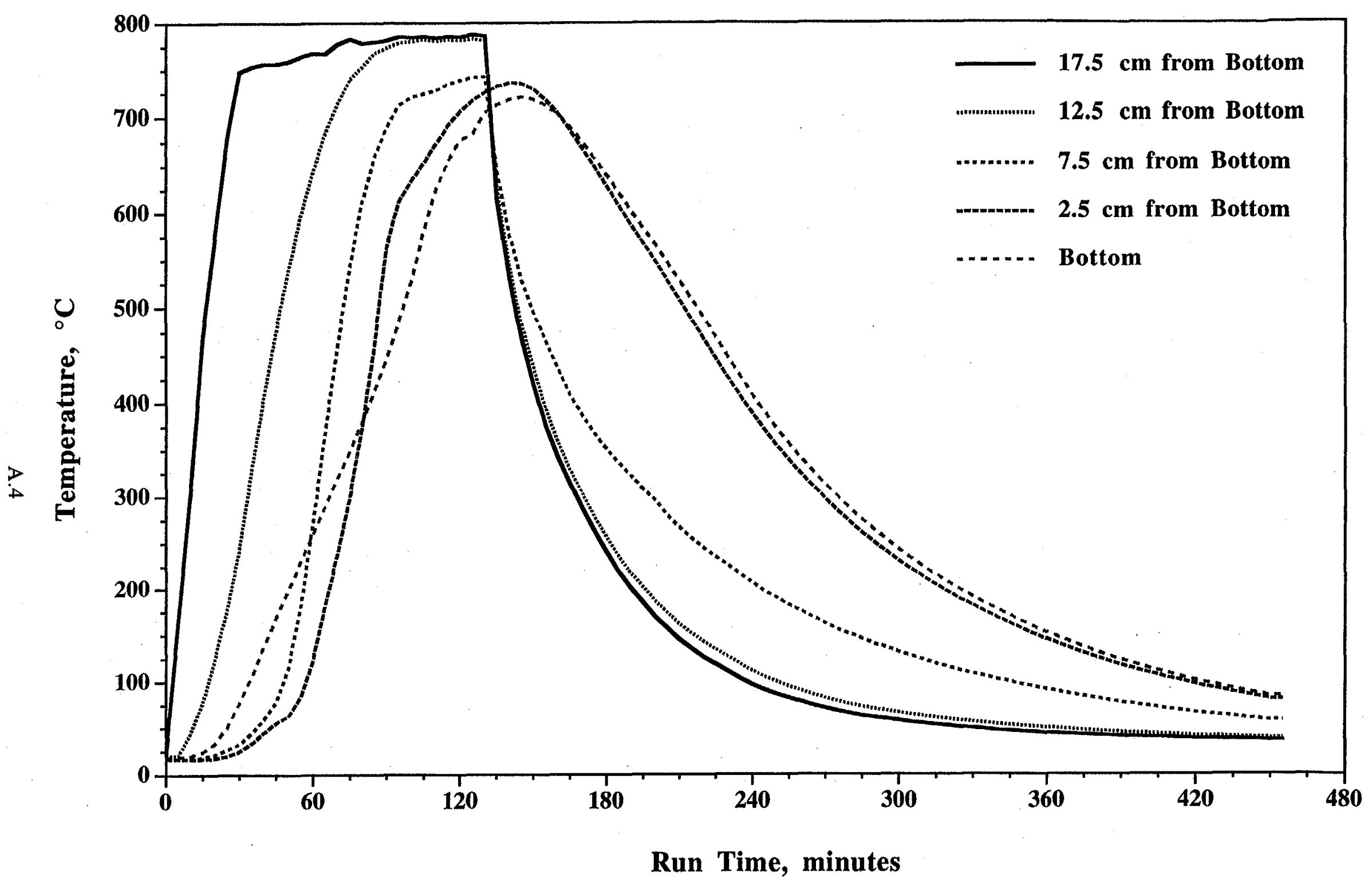

Figure A.4. Test \#4: Calcined Mix C and Fine NBS-1 Glass Frit 


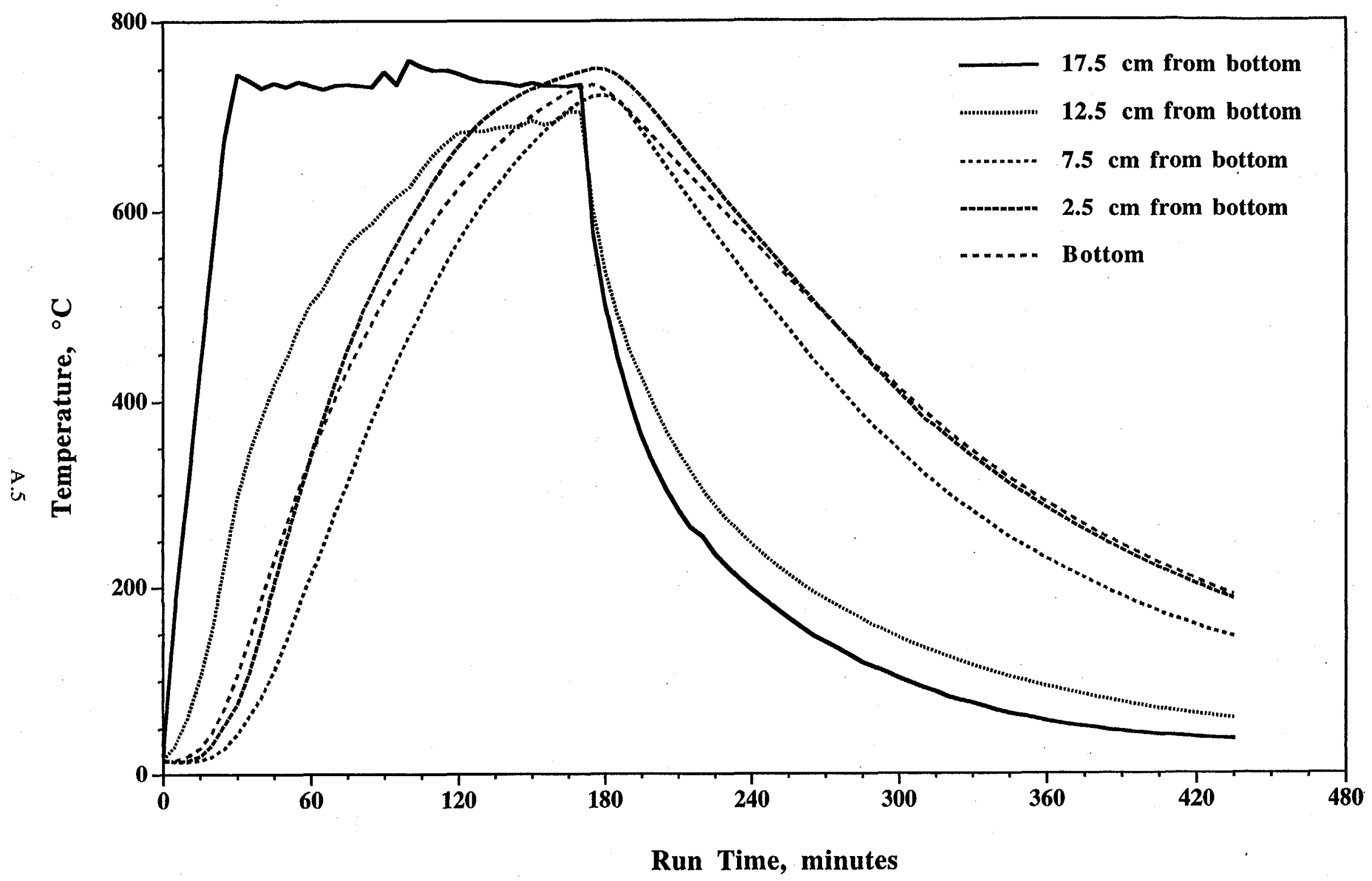

Figure A.5. Test \#5: Calcined Mix B, Calcined U of M, and Coarse NBS-1 Glass Frit 


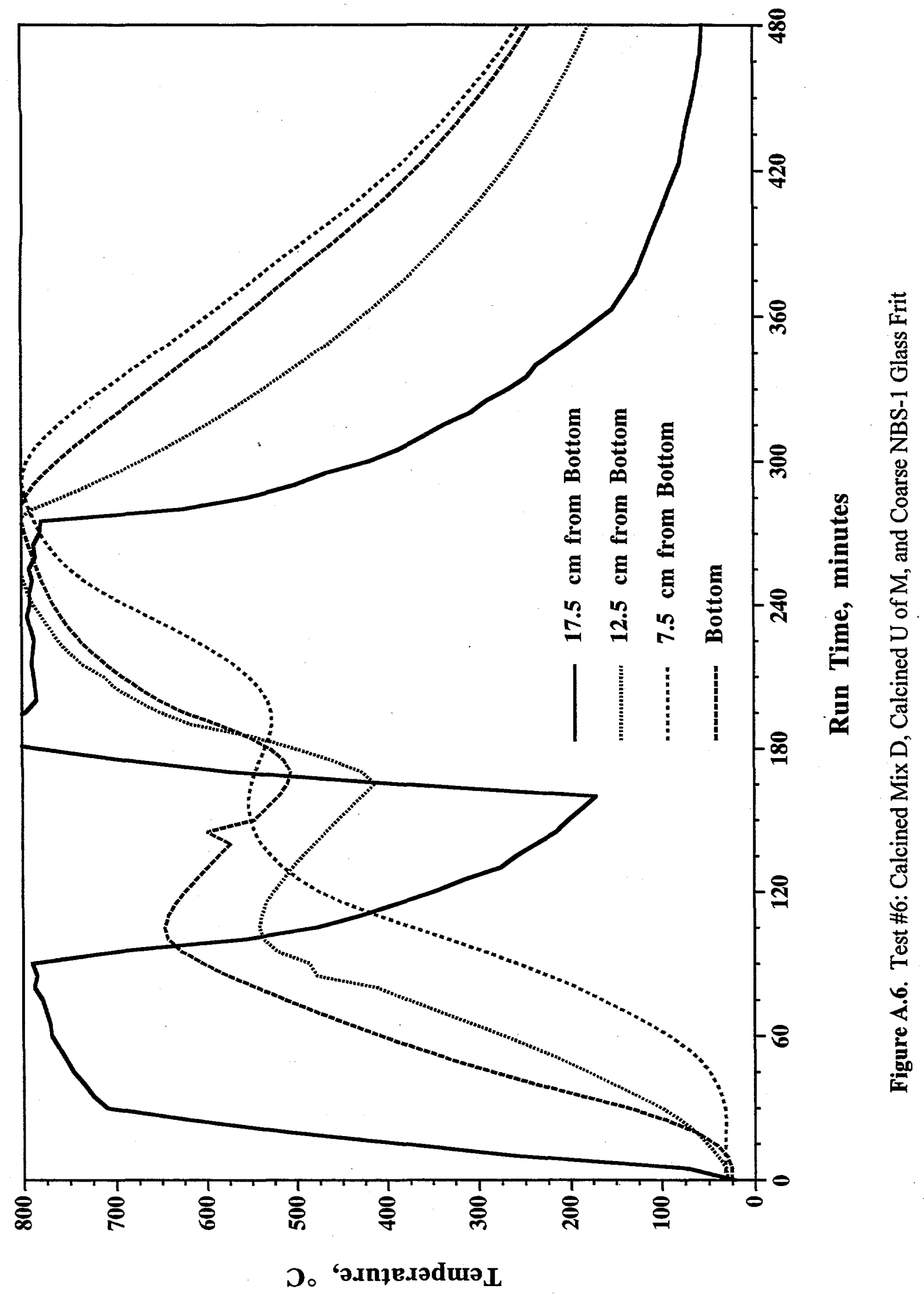

A. 6 


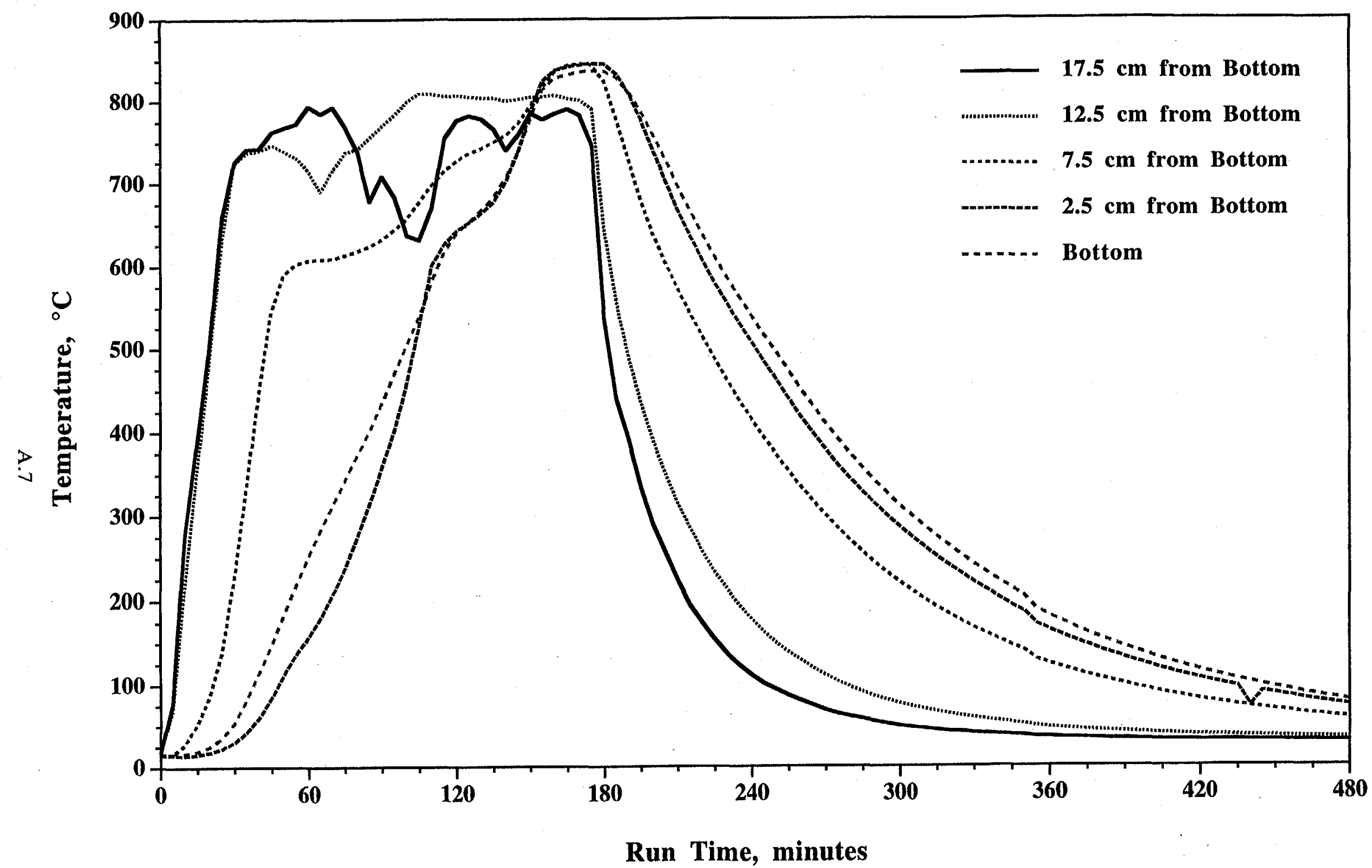

Figure A.7. Test \#7: Uncalcined Mix A and Fine NBS-1 Glass Frit 


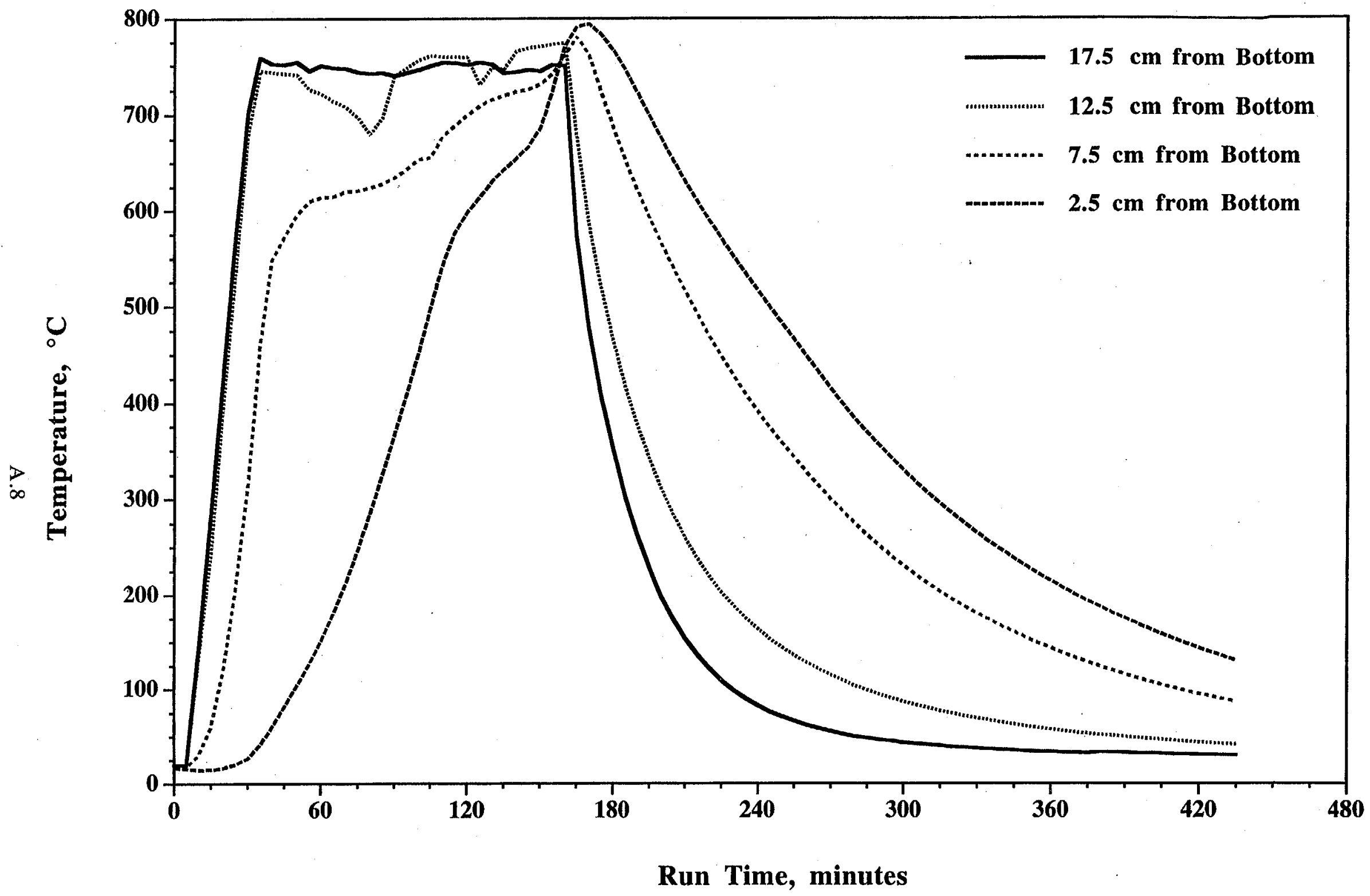

Figure A.8. Uncalcined U of M and Fine NBS-1 Glass Frit 


\section{Distribution}

No. of

Copies

Offsite

2 Office of Scientific and Technical Information

9 Los Alamos National Laboratory P.O. Box 1663 Los Alamos, NM 87545

Attn: Rick Ames Steve McKee (5)

Gerry Veazey

Ron Nakaoka

Steve Yarbro

10 Rocky Flats Environmental

Technology Site

P.O. Box 464

Golden, CO 80402

Attn: Chris Bader (5)

Mike Tien

A1 Philips

Dave Moody

Steve Scott

Don Thorp

Tracy Rudesill

Westinghouse Savannah River Co.

Aiken, SC 29808
No. of

Copies

Onsite

4 B\&W Hanford

M.W. Gibson

T5-55

R.C. Hoyt

$\mathrm{N} 1-20$

R.W. Szempruch

T5-48

T.J. Venetz

$\mathrm{N} 1-20$

24 Pacific Northwest National Laboratory

W.B. Andrews

K7-97

J.L. Buelt

K9-09

J.G. Darab

K3-59

M.L. Elliott

K6-24

R.J. Elovich

P7-25

P.R. Hrma

K6-24

H. Li

K6-24

J.P. LaFemina

P7-27

L.M. Peurrung

K6-28

A.W. Prichard

K8-34

R.K. Quinn

K9-69

R.D. Scheele

P7-25

M.J. Schweiger

K6-24

J.D. Vienna (5)

K6-24

Information Release (5) 